\title{
9. COMPOSITION AND ORIGIN OF Cr-RICH GLAUCONITIC SEDIMENTS FROM THE SOUTHERN KERGUELEN PLATEAU (SITE 748) ${ }^{1}$
}

\author{
Peter Rene Bitschene, ${ }^{2}$ Mary Anne Holmes,${ }^{3}$ and James R. Breza ${ }^{4}$
}

\begin{abstract}
Five hundred meters of a unique Upper Cretaceous Cr-rich glauconitic sequence (Unit III) that overlies a 3-m-thick alkali-basalt flow with underlying epiclastic volcanogenic sediments was drilled at ODP Leg 120 Site 748. The $\mathrm{Cr}$-rich glauconitic sequence is lithostratigraphically and biostratigraphically divided into three subunits (IIIA, IIIB, IIIC) that can also be recognized by the $\mathrm{Cr}$ concentration of the bulk sediment, which is low $(<200 \mathrm{ppm})$ in Subunits IIIC and IIIA and high (400-800 ppm) in Subunit IIIB. The $\mathrm{Cr}$ enrichment is caused by $\mathrm{Cr}$-spinel, which is the only significant heavy mineral component beside $\mathrm{Fe}$ - $\mathrm{Ti}$ ores. Other $\mathrm{Cr}$-bearing components are glauconite pellets and possibly some other clay minerals.

The glauconitic sequence of Subunit IIIB was formed by reworking of glauconite and volcanogenic components that were transported restricted distances and redeposited downslope by mass-transportation processes. The site of formation was a nearshore, shallow inner shelf environment, and final deposition may have been on the outer part of a narrow shelf, at the slope toward the restricted, probably synsedimentary, faulted Raggatt Basin.

The volcanic edifices uncovered on land were tholeiitic basalts (T-MORB), alkali-basaltic (OIB) and (?)silicic volcanic complexes, and ultramafic rocks. The latter were the ultimate source for the $\mathrm{Cr}$-spinel contribution. Terrestrial aqueous solutions carried $\mathrm{Fe}, \mathrm{K}, \mathrm{Cr}, \mathrm{Si}$, and probably $\mathrm{Al}$ into the marine environment, where, depending on the redox conditions of microenvironments in the sediment, green ( $\mathrm{Fe}$ - and $\mathrm{K}$-rich) or brown (Al-rich) glauconite pellets formed.

The Upper Cretaceous glauconitic sequence at Site 748 on the Southern Kerguelen Plateau constitutes the transition in space and time from terrestrial to marine, from magmatically active subaerial to magmatically passive submarine conditions, and from a tranquil platform to active rifting conditions.
\end{abstract}

\section{INTRODUCTION}

Ocean Drilling Program (ODP) Site 748 is located at $58^{\circ} 26.45^{\prime} \mathrm{S}, 78^{\circ} 58.89^{\prime} \mathrm{E}$, on the Southern Kerguelen Plateau in the western part of the Raggatt Basin, east of Banzare Bank, in a water depth of $1240.5 \mathrm{~m}$ (Fig. 1). A 510 -m-thick sequence of Cr-rich glauconitic sediments was recovered from 389.1 to $898.8 \mathrm{~m}$ below seafloor (mbsf), beneath Cenozoic calcareous and siliceous ooze and chalk with chert, at Hole $748 \mathrm{C}$. The basal part of the glauconitic sequence is a 3 -m-thick alkalibasalt flow.

The dominant features of this Upper Cretaceous (Cenomanian/?Turonian-Maestrichtian) sediment are its (1) enrichment in glauconite pellets, which constitute $10 \%-90 \%$ of the sediment; (2) overall $\mathrm{Cr}$ enrichment of the glauconitic sediment; (3) great thickness $(500 \mathrm{~m})$ restricted to the Kerguelen Plateau; and (4) significant content of volcaniclastic material although lacking transparent heavy minerals (Bitschene et al., 1989).

Several other occurrences of Cretaceous glauconitic sediment in and around the Indian Ocean (Fig. 2) can be grouped into three principal periods of abundant glauconite deposition: Neocomian, Albian-Coniacian, and Campanian-Maestrichtian. Neocomian greensands were deposited in the Barrow sub-basin of the Carnarvon Basin (Playford et al., 1975) and at Deep Sea Drilling Project (DSDP) Site 258 on the Naturaliste

\footnotetext{
${ }^{1}$ Wise, S. W., Jr., Schlich, R., et al., 1992. Proc. ODP, Sci. Results, 120: College Station, TX (Ocean Drilling Program).

2 Institut für Mineralogie, Ruhr Universităt Bochum, Postfach 102148 , D-4630 Bochum, Federal Republic of Germany.

${ }^{3}$ Geology Department, 330 Bessey Hall, University of Nebraska, Lincoln, NE 68588-0340, U.S.A. U.S.A.
}

Plateau (Davies, Luyendyk, et al., 1974). During the Albian to Coniacian (and possibly as late as middle Santonian), the Osborne Formation, comprising $60-200 \mathrm{~m}$ of glauconitic sandstones, claystones, and minor greensands, was deposited in the Perth Basin (Playford et al., 1975), while brown to dark green nonfossiliferous glauconitic siltstones formed at Site 748. Limestones with as much as $15 \%$ glauconite pellets at Sites 747 and 738 (Barron, Larsen, et al., 1989) are dated as Turonian-Coniacian and correlate with the upper lithologic Subunit IIIB at Site 748. The Molecap Greensand in the Perth Basin comprises $10-12 \mathrm{~m}$ of sediment rich in glauconite pellets and lies above the Cenomanian Osborne Formation beds and below the middle Santonian Gingin Chalk. Glauconitic sediment fills cracks and fissures in Santonian limestone at DSDP Site 255 on Broken Ridge (Davies, Luyendyk, et al., 1974). During the Campanian and (mostly early) Maestrichtian, greensands formed in volcaniclastic claystones at DSDP Site 216 at the extreme northern end of Ninetyeast Ridge (von der Borch, Sclater, et al., 1974). Lithologic Subunit IIIA was deposited at Site 748, and the Poison Hill Greensand formed in the Perth Basin (Playford et al., 1975).

Although the formation of glauconite pellets was not a rare event in the early history of the Indian Ocean, the deposition of glauconite pellets was sustained almost without interruption at Site 748 .

\section{OBJECTIVES AND TERMINOLOGY}

The objective of this study is to determine the composition and origin of the (1) Cr-bearing components, (2) volcanogenic components, (3) neoformed minerals, and (4) bulk sediment (i.e., all the epiclastic, bioclastic, and neoformed components) so as to elucidate the volcanotectonic evolution of the Raggatt Basin on the Southern Kerguelen Plateau during the Late Cretaceous and to reconstruct the paleoceanographic conditions that contributed to the deposition of the glauconite pellets. 


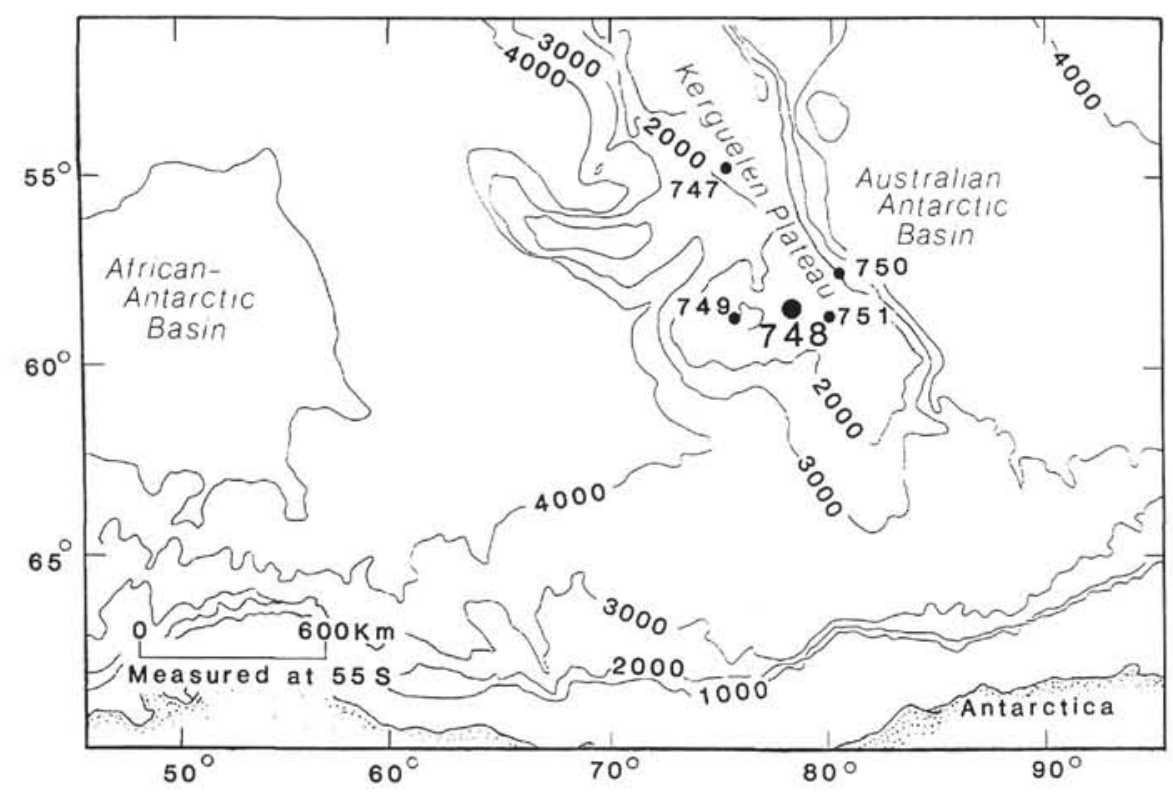

Figure 1. Morphotectonic units in the southern and eastern Indian Ocean and location of Leg 120 drill sites on the Central and Southern Kerguelen Plateau. Bathymetry in meters.

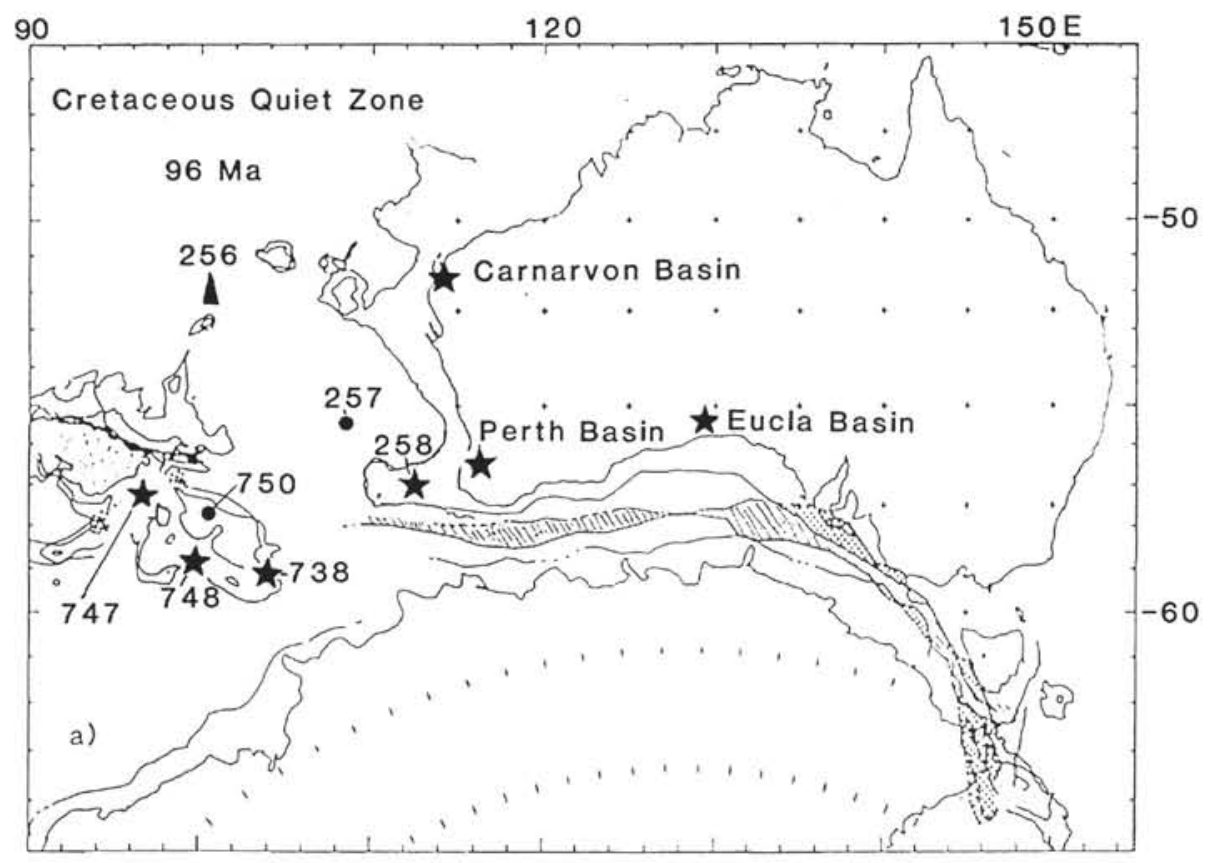

$\star$ Sites with Glauconitic Sediment, Greensands. (see TABLE 1)

$\$$ Sites with Traces of Glauconite.

- Sites with no Traces of Glauconite.

Figure 2. Occurrence of Upper Cretaceous glauconitic sediments in the Indian Ocean and surrounding geographic region. Reconstruction from Royer and Sandwell (1989).

It is not our purpose to review in general the origin and composition of glauconite pellets. Previous investigations and summaries by Bell and Goodell (1967), Bentor and Kastner (1965), Bornhold and Giresse (1985), Burst (1958), Fischer (1987), Galliher (1939), Hower (1961), Hughes and Whitehead (1987), McRae (1972), Odin (1972, 1988a, 1988b), Odin and
Matter (1981), Odin and Fullagar (1988), Thompson and Hower (1975), and Triplehorn (1966) have thoroughly discussed the composition and origin of glauconite pellets and their use as stratigraphic and paleoenvironmental indicators. We offer the following summary of the formation of glauconite pellets from their work: 
1. The term "glauconite" has two meanings in its usage. As a morphologic term, it refers to monomineralic or polymineralic green pellets. As a mineralogic term, it refers to a dominantly dioctahedral, K-rich ferric mica of specific chemical composition (Warshaw, 1957, in Bailey, 1980). Following Burst (1958), Bentor and Kastner (1965), and Thompson and Hower (1975), we refer to green pellets as "glauconite pellets" and reserve the term "glauconite" for ferric mica, where it has been identified by X-ray-diffraction (XRD) analysis. Our term "glauconite pellet" is equivalent to Odin and Matter's (1981) term "glaucony."

2. Glauconite pellets or films may form as internal molds of calcareous bioclasts and replace almost any mineral, including calcite, biotite, feldspar, quartz, lithic fragments, and volcanic glass shards. They also replace fecal pellets and may develop as a film around other grains or as a precipitate in pore space.

3. Glauconite pellets usually form in open, shallow-marine environments on the continental shelf, where redox potentials are approximately zero and there is a high level of biogenic activity.

4. Glauconite pellets occur through a wide age range, from Precambrian to Holocene sediments, and in a wide variety of sediment types, from calcareous to siliciclastic.

5. Glauconitic sediments serve as a sink for $\mathrm{Fe}$ and $\mathrm{K}$; other elements (e.g., $\mathrm{Cr}$ ) may be incorporated as a result of local conditions.

6. Glauconite pellets and film are not reliable indicators of water depth or temperature but generally form under normal marine conditions. Nonmarine glauconite pellets are richer in $\mathrm{Mg}$ than are the marine types (McRae, 1972).

\section{METHODS}

Thirty-five samples were taken from half-round cores, cleaned, and rinsed with distilled water to remove external contamination. Thin sections from each sample were examined with transmitted light. Ore microscopy was performed on polished thin sections in reflected light, partly with an oilimmersed objective. Mineral compositions were determined from polished thin sections using a CAMEBAX automated microprobe at $15 \mathrm{kV} / 8 \mathrm{nA}$ (glauconite, sheet silicates; defocused beam) and $15 \mathrm{kV} / 14 \mathrm{nA}$ (ore minerals, feldspar; focused and defocused beam) operating conditions. Natural oxide standards were analyzed for major element and $\mathrm{Cr}$ calibration. The major and trace element compositions of the bulk sediment were determined by X-ray fluorescence (XRF) techniques (Philips PW 1401 spectrometer) on fused glass beads.

For mineralogic analysis, the fine and coarse fractions were separated by wet-sieving through a $64-\mu \mathrm{m}$ screen with distilled water. The fines were separated into phi classes 4 through 11 by standard pipette methods (e.g., Lewis, 1984, p. 88 ) and were mounted onto glass slides using the modified membrane filtration technique of Pollastro (1982) to orient the clay. The samples were analyzed with a Philips APD 3520 $\mathrm{X}$-ray diffractometer set at $40 \mathrm{kV}$ and $20 \mathrm{~mA}$. The coarse material was separated into magnetically susceptible (mostly glauconite pellets) and nonsusceptible (mostly carbonate, quartz, and feldspar) fractions using a Frantz isodynamic separator set at $1 \mathrm{amp}$ and with an $18^{\circ}$ tilt. The samples were passed through the separator 2 or 3 times.

Unground samples were loosely packed (unoriented mounts) and X-rayed untreated from $2^{\circ}$ to $65^{\circ} 2 \theta$. A subsample was then gently ground in distilled water with a ceramic mortar and pestle. The material in suspension was siphoned off and allowed to dry on a glass slide to produce oriented mounts. These were X-rayed from $2^{\circ}$ to $65^{\circ} 2 \theta$ untreated, from $2^{\circ}$ to $30^{\circ} 2 \theta$ treated with ethylene glycol (over vapor at $60^{\circ} \mathrm{C}$ overnight), and from $2^{\circ}$ to $15^{\circ} 2 \theta$ after heating for $3 \mathrm{hr}$ at $350^{\circ} \mathrm{C}$.
The percentage of interlayered mineral was estimated by comparison with the calculated patterns of Thompson and Hower (1975).

To determine whether the $\mathrm{Cr}$ occurs adsorbed to the glauconite pellet mineral or is part of the crystal lattice, another subsample of the magnetically susceptible coarse fraction was ground in distilled water and soaked in $1 \mathrm{~N}$ ammonium acetate ( $\mathrm{pH} 7.0$ ) overnight to remove exchangeable cations (1:25 sample to liquid; Chapman, 1965). The solid was filtered out using a suction filtration apparatus. The filtrate was analyzed for $\mathrm{Cr}$ using a Perkin-Elmer 2380 atomic absorption spectrophotometer with a sensitivity of $0.5 \mathrm{mg} / \mathrm{L}$ $\left(9.6 \times 10^{-6} \mathrm{mmole} / \mathrm{mL}\right)$. The same samples were examined in a JEOL model T-330 scanning electron microscope (SEM), equipped with a Kevex energy dispersive X-ray analyzer (EDX), for the presence of Cr. Several clay samples were analyzed for elemental composition.

Fifteen samples of varying textures were taken from Cores 120-748C-56R through 120-748C-78R and disaggregated by soaking in distilled water for $24 \mathrm{hr}$. They were then dried, weighed, wet-sieved through a $64-\mu \mathrm{m}$ screen using distilled water, and dried and weighed again to determine the sand, silt, and clay (mud) fractions. The mud fraction was saved for XRD analysis. The sand fraction was sieved into $0.5-\phi$ intervals using an Allen-Bradley sonic sifter. The mean, standard deviation, skewness, and kurtosis were calculated using Kirkpatrick's (1982) granulometric statistical program. The mean, standard deviation, and correlation coefficients $(r$ values) for the glauconitic sand textural analysis were calculated using the Lotus 1-2-3 statistical regression package.

\section{RESULTS}

\section{Stratigraphic Summary}

Lithologic Unit III at Site 748 is divided into three subunits based on the varying proportions of glauconite to other constituents (Fig. 3): (1) basal alkali-basalt cobble conglomerate (Subunit IIIC); (2) glauconitic, noncalcareous sandstones, siltstones, and claystones (Subunit IIIB); and (3) glauconitic, calcareous, bioclastic sediment (Subunit IIIA).

Subunit IIIA occurs in Sections 120-748C-27R-CC through $120-748 \mathrm{C}-56 \mathrm{R}-\mathrm{CC}$ (389.1-692.0 mbsf) and is composed of rudstones, grainstones, packstones, and wackestones, which contain from $5 \%$ to $58 \%$ glauconite pellets ("Frontispiece," this volume; Plate 1, Figs. 1 and 2). A major constituent of this subunit is bioclastic material composed primarily of fine sand to granule-sized debris of bryozoans, inoceramids, foraminifers, echinoids, sponges, mollusks, radiolarians, crinoids, and red algae ("Frontispiece," this volume). Overall, the clay content in Subunit IIIA increases downhole. The clay-sized sediment is composed largely of micrite and clay minerals. Micrite decreases downhole, whereas clay mineral content increases.

Subunit IIIB occurs in Core 120-748C-57R through Section $120-748 \mathrm{C}-79 \mathrm{R}-4,58 \mathrm{~cm}(692.0-897.6 \mathrm{mbs})$. This subunit contains only rare carbonate bioclasts. The major constituents in the upper section of Subunit IIIB are glauconitic sandstones and clayey sandstones. Siltstones, clayey siltstones, and claystones are the dominant lithology in the lower part of Subunit IIIB. The sandstones occur from Cores $120-748 \mathrm{C}-58 \mathrm{R}$ through $-61 \mathrm{R}$ and are composed primarily of glauconite pellets and silicified fossils (Schlich, Wise, et al., 1989). Sandstone is not present below 732.5 mbsf (Core 120-748C-61R); the siltstones and clayey siltstones containing 5\%-96\% glauconite pellets continue through Section 120-748C-79R-3 (897.6 mbsf; Fig. 3). The interval between 732.5 and 897.6 mbsf is massive, 


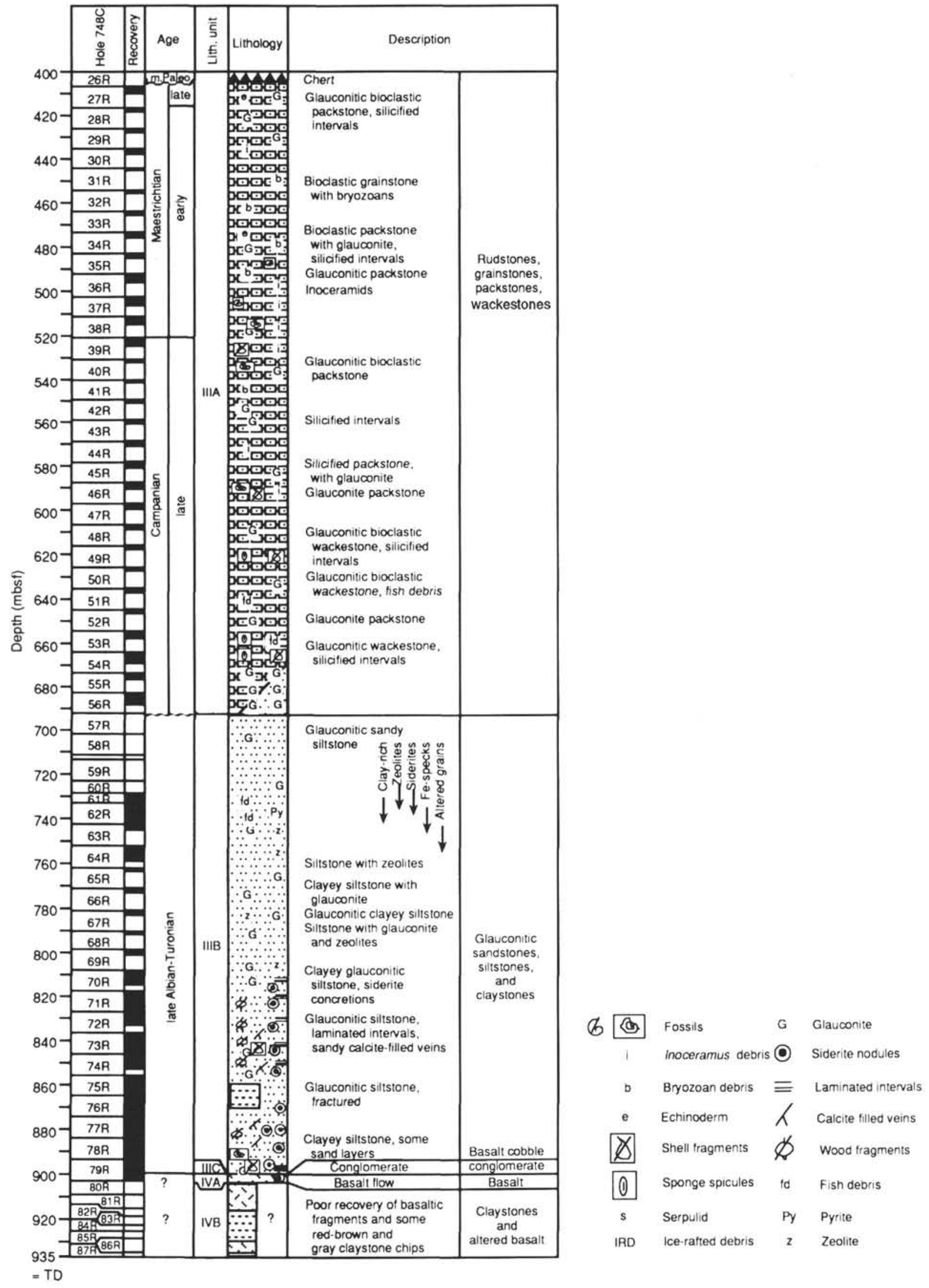

Figure 3. Stratigraphic division of the lithology at Site 748. 
Table 1. Weight percent of selected samples from lithologic Unit III "glauconitic sequence," Hole 748C.

\begin{tabular}{lcccccc}
\hline $\begin{array}{c}\text { Core, section, } \\
\text { interval (cm) }\end{array}$ & $\begin{array}{c}\text { Depth } \\
\text { (mbsf) }\end{array}$ & $\begin{array}{c}\text { Friability } \\
\text { rating* }\end{array}$ & $\begin{array}{c}\text { Mud } \\
(\%)\end{array}$ & $\begin{array}{c}\text { Sand } \\
(\%)\end{array}$ & $\begin{array}{c}\text { Sand: } \\
\text { Mud }\end{array}$ & $\begin{array}{c}\text { Textural } \\
\text { class }\end{array}$ \\
\hline 120-748C- & & & & & & \\
56R-3, 59-63 & 682.09 & 2 & 26.8 & 73.2 & 2.7 & MS \\
61R-1, 88-93 & 728.38 & 3 & 55.1 & 44.9 & 0.8 & SM \\
62R-2, 72-76 & 734.72 & 3 & 82.9 & 17.1 & 0.2 & SM \\
63R-1, 67-71 & 742.67 & 1 & 60.0 & 40.0 & 0.7 & SM \\
65R-1, 62-66 & 761.62 & 1 & 48.2 & 51.8 & 1.1 & MS \\
66R-1, 52-56 & 771.02 & 1 & 70.3 & 29.7 & 0.4 & SM \\
67R-1,117-121 & 781.17 & 1 & 38.6 & 61.4 & 1.6 & MS \\
68R-1, 67-73 & 790.19 & 1 & 58.5 & 41.5 & 0.7 & SM \\
69R-1, 97-101 & 798.47 & 1 & 66.9 & 33.1 & 0.5 & SM \\
70R-1, 93-97 & 807.93 & 1 & 53.9 & 46.1 & 0.9 & SM \\
71R-3, 81-85 & 820.31 & 1 & 49.8 & 50.2 & 1.0 & MS \\
72R-3, 134-139 & 830.84 & 2 & 48.9 & 51.1 & 1.0 & MS \\
74R-1, 80-83 & 845.80 & 1 & 90.2 & 9.8 & 0.1 & SM \\
75R-3, 86-90 & 858.36 & 1 & 52.6 & 47.4 & 0.9 & SM \\
77R-6, 49-53 & 881.49 & 2 & 25.3 & 74.7 & 3.0 & MS \\
\hline Average & & & 55.2 & 44.8 & 1.0 & \\
SD & & & 17.3 & 17.3 & 0.8 & \\
Minimum & 682.09 & & 25.3 & 9.8 & 0.1 & \\
Maximum & 881.49 & & 90.2 & 74.7 & 3.0 & \\
Count & 15 & & 15 & 15 & 15 & \\
\hline
\end{tabular}

Notes: The friability rating is the degree to which a sample can be crushed by one's fingernail, with $1=$ very friable, $2=$ friable, and $3=$ slightly friable. MS = muddy sand and $\mathrm{SM}=$ sandy mud. $\mathrm{SD}=$ standard deviation

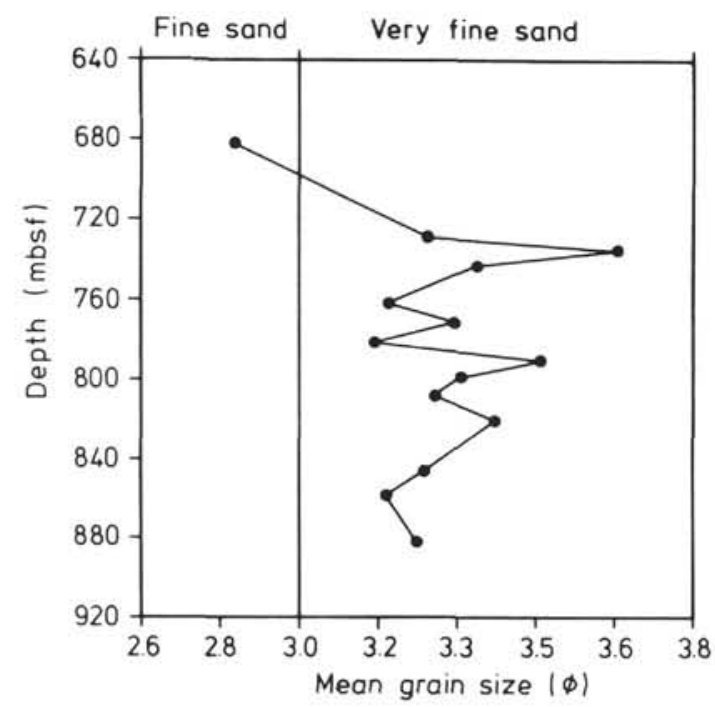

Figure 4. Vertical distribution of mean grain size.

bioturbated, and laminated to bedded or cross-laminated/ bedded (Plate 1, Fig. 3).

Subunit IIIC occurs from Sections 120-748C-27R-CC, 58 $\mathrm{cm}$, through -79R-5, $25 \mathrm{~cm}$ (897.6-898.8 mbsf; Fig. 3). This subunit is a conglomerate composed of rounded, altered basalt cobbles and boulders, unaltered broken mollusk shells, and a matrix of glauconitic calcareous siltstones with altered volcanic debris (Plate 1, Fig. 4; "Frontispiece," this volume).

\section{Textural Analysis of the Glauconitic Sand Fraction}

The sand to mud ratio varies, but has no systematic relationship with depth (Table 1). The mean grain size varies from 2.91 to $3.69 \phi$ (81 to $130 \mu \mathrm{m}$, very fine to fine sand), with an overall mean of $3.32 \phi(99 \mu \mathrm{m})$ (Fig. 4). The glauconitic sand size ranges do not correlate to depth.

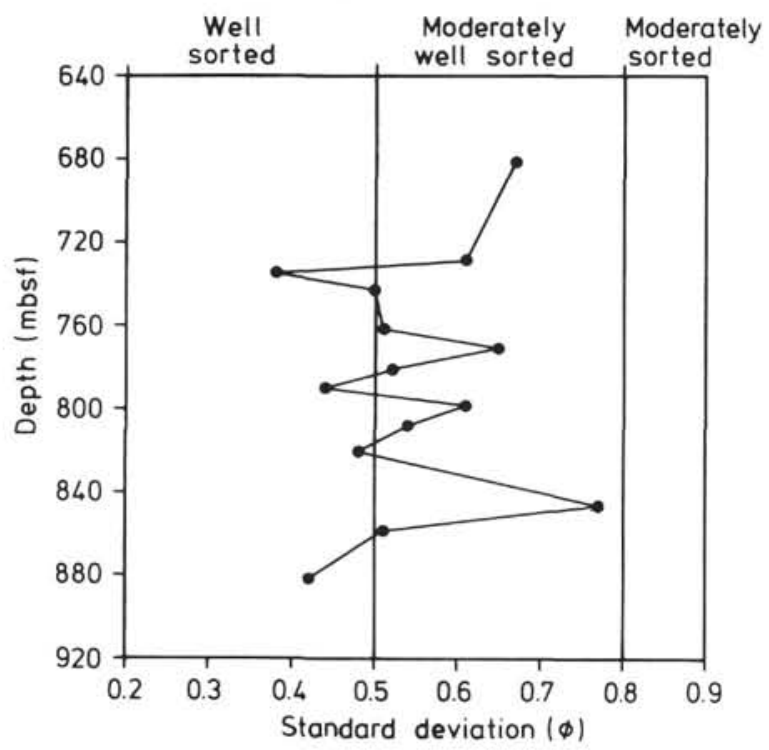

Figure 5. Vertical distribution of sorting.

Table 2. Textural analysis of the sand fraction of selected samples from lithologic Unit III "glauconitic sequence," Hole 748C.

\begin{tabular}{lccccc}
\hline $\begin{array}{c}\text { Core, section, } \\
\text { interval }(\mathrm{cm})\end{array}$ & $\begin{array}{c}\text { Depth } \\
\text { (mbsf) }\end{array}$ & $\begin{array}{c}\text { Mean } \\
(2 \theta)\end{array}$ & SD & Skewness & Kurtosis \\
\hline 120-748C- & & & & & \\
56R-3, 59-63 & 682.09 & 2.910 & 0.678 & -0.120 & 1.9 \\
61R-1, 88-93 & 728.38 & 3.302 & 0.613 & -0.437 & 3.5 \\
62R-2, 72-76 & 734.72 & 3.688 & 0.377 & -0.531 & 3.6 \\
63R-1, 67-71 & 742.67 & 3.402 & 0.504 & -0.416 & 3.4 \\
65R-1, 62-66 & 761.62 & 3.221 & 0.510 & -0.332 & 3.8 \\
66R-1, 52-56 & 771.02 & 3.357 & 0.652 & -0.687 & 4.4 \\
67R-1, 117-121 & 781.17 & 3.192 & 0.523 & -0.303 & 3.7 \\
68R-1, 69-73 & 790.19 & 3.533 & 0.442 & -0.756 & 7.0 \\
69R-1,97-101 & 798.47 & 3.368 & 0.609 & -0.572 & 4.1 \\
70R-1, 93-97 & 807.93 & 3.314 & 0.537 & -0.458 & 4.0 \\
71R-3, 81-85 & 820.31 & 3.438 & 0.480 & -0.531 & 5.0 \\
72R-3, 134-139 & 830.84 & NA & NA & NA & NA \\
74R-1, 80-83 & 845.80 & 3.295 & 0.770 & -0.530 & 3.0 \\
75R-3, 86-90 & 858.36 & 3.216 & 0.513 & -0.292 & 3.4 \\
77R-6, 49-53 & 881.49 & 3.279 & 0.419 & -0.371 & 4.4 \\
\hline Average & & & & & \\
SD & & 3.101 & 0.508 & -0.422 & 3.7 \\
Minimum & 682.09 & 0.000 & 0.000 & -0.756 & 0.0 \\
Maximum & 881.49 & 3.688 & 0.770 & 0.000 & 7.0 \\
Count & 15 & 15 & 15 & 15 & 15 \\
\hline
\end{tabular}

Note: $\mathrm{SD}=$ standard deviation and $\mathrm{NA}=$ not analyzed.

The degree of sorting (standard deviation) in the glauconitic sand shows no predictable trends with depth $(r=0.142)$. Pettijohn et al. (1973) showed that high standard deviation values in quartz sand indicate frequent reworking by currents of moderate intensity. Our high standard deviation values may indicate reworking of the glauconite pellets by moderate- to low-energy currents. In addition, cross-bedding and crosslamination in Subunit IIIB (Plate 1, Fig. 3) also indicate reworking. Classifying the sands into sorting classes according to standard deviation shows that the degree of sorting varies from well sorted $(0.377)$ to moderately well sorted (glauconitic sands). Sorting vs. depth is shown in Figure 5. All samples are negatively skewed (Table 2 ) and show no trends in skewness with depth $(r=0.201)$. Kurtosis also shows no relationship with depth $(r=0.340)$. According to Friedman 
(1962), such textural results coincide with a shallow to distal marine shelf depositional environment.

\section{Sediment Petrography}

The sediment composition has detrital and authigenic components. The detrital portion includes both inorganic and biogenically derived components. Inorganic detrital components include lithic clasts, light minerals, opaque minerals, and clay. Biogenic detrital components include carbonate debris and minor amounts of phosphate and carbonaceous matter. The authigenic components include glauconite pellets, carbonate cement, zeolite, and silica.

\section{Inorganic Detrital Components}

The common characteristics of the inorganic detrital components are (1) their volcanogenic origin, (2) the nearly complete absence of transparent heavy minerals, and (3) the complete absence of any material derived from metamorphic or silicic magmatic continental crust.

\section{Lithic Clasts}

The lithic clasts comprise the round pebbles of the basal conglomerate, soft-sediment pebbles (rip-up clasts in Cores 120-748C-49R, -50R, -73R, and -77R), and chert fragments. Highly altered basaltic lithic fragments of undeterminable origin were observed in one shipboard smear slide (Sample $120-748 \mathrm{C}-31 \mathrm{R}-\mathrm{CC}, 30 \mathrm{~cm}$ ).

The basaltic clasts from the basal conglomerate (Core $120-748 \mathrm{C}-79 \mathrm{R}$ ) range from $40 \mathrm{~cm}$ to a few millimeters in diameter and are well rounded. Many are coated by sparry calcite, which also occurs in cracks within the clasts and as pseudomorphs after primary plagioclase. The clasts (Plate 2, Fig. 3) are derived unquestionably from the underlying alkalibasalt flow and have been intensively altered and bleached to shades of light gray-brown. The largest boulder is cut by white siderite and analcime veins. No glassy rim is evident on the clasts, suggesting that they were rounded after cooling and erosion of the underlying alkali-basalt flow. Other than a few plagioclase remnants (70 $\mu \mathrm{m}$ long), all primary constituents have been replaced by green sheet silicates, zeolite, spongy $\mathrm{Fe}-\mathrm{Ti}$ ores, and carbonate. Clay aggregates show radial growth on brown, palagonite-like material. The primary shapes of minerals can be inferred from pseudomorphs after olivine and from the circular alignment of tiny ore specks $(<30$ $\mu \mathrm{m}$ diameter) characteristic of former feldspathoids (leucite?). The basaltic pebbles are set into a matrix of glauconite pellets, shell debris, and altered volcanogenic debris.

The intraformational rip-up clasts consist of a clayey, brownish matter, locally with some opaque substance or with a few glauconite grains, which do not exceed $10 \%$. These clasts are flattened and clay-rich and bear appreciably more neoformed carbonate rhombs, framboidal pyrite, and black carbonaceous matter than the silty-to-sandy glauconitic sediment enclosing them. The detrital clay is a randomly interstratified smectite-mica of nontronite-glauconite composition (Holmes, this volume). The composition indicates a confined, reducing paleomicroenvironment for the rip-up clasts.

\section{Light Mineral Assemblage}

The detrital mineral assemblage distinctly lacks transparent heavy minerals except for a few zircons. Clear, angular to subrounded plagioclase splinters (as long as $210 \mu \mathrm{m}$ ) are pervasive throughout the sediment. Some appear corroded and are altered to or replaced by green clay minerals in the core. Clear volcanic quartz occurs in Subunit IIIB, accompanied by some plagioclase and rare, altered, angular sanidine (anorthoclase with a high Fe content). Brownish, round to blocky, quasi-isotropic grains appear to be altered glass shards. The freshest but still chemically altered glass shards occur within sparry carbonate (Plate 2, Fig. 4). Rare brown pleochroic biotite remnants and biotite intergrown with spongy opaque minerals are also embedded in carbonate. In one sample, tiny $(<10 \mu \mathrm{m})$ picotite crystals are set into a green mineral aggregate, which appears to have been olivine. Sample $120-748 \mathrm{C}-56 \mathrm{R}-2,137-144 \mathrm{~cm}$, bears a completely red, elongate prism of hematite and clay mineral pseudomorphs after olivine or pyroxene.

\section{Opaque Mineral Assemblage}

The opaque paragenesis consists of pyrite (neoformed framboidal aggregates and idiomorphic cubes), ilmenite, Timagnetite, rutile/leucoxene aggregates after primary ilmenite, brown translucent $\mathrm{Cr}$-spinel and opaque chromite, chalcopyrite(?), and various red iron oxides and hydroxides. Throughout the $500-\mathrm{m}$-thick glauconitic sequence, this paragenesis remains the same. Differences in grain size follow the trend of the glauconite grain size, but because of the higher specific weight, the average opaque grain sizes are about $50 \%-70 \%$ smaller than the average glauconitic pellet size. The basal conglomerate contains large $\mathrm{Cr}$-spinel grains (as thick as 2 $\mathrm{mm}$ ) with Fe-rich dissolution lamellae. The heavier particles are dispersed throughout the sediment and are not concentrated in layers or lenses.

Authigenic pyrite occurs as $<40-\mu$ m-large idiomorphic cubes and framboidal aggregates, indicating in situ formation. Some fossils are pyritized. Clay-rich lenses a few millimeters thick with abundant neoformed carbonate rhombs are significantly enriched in tiny pyrite crystals and framboids and are devoid of detrital opaque components and glauconite.

Detrital opaque phases are spinellide of a varying composition. Cr-spinel occurs in large, semitranslucent, rounded grains (as much as $2 \mathrm{~mm}$ in diameter; Plate 2, Fig. 1) with reddish brown shades that match the Cr-spinel xenocrysts of the underlying alkali basalts. The $\mathrm{Cr}$-spinel is highly homogeneous. Only a few magnetite specks $(<10 \mu \mathrm{m}$, possibly pseudomorphs after primary inclusions) are enclosed. Smaller $\mathrm{Cr}$-spinel grains are found throughout the sequence, as well as angular chromite. Ilmenite and magnetite are present as rhombohedral and octahedral splinters in various stages of mechanical rounding and decomposition. Some spinel grains have a hematite rim a few microns thick.

Rutile/leucoxene aggregates, pseudomorphs after primary Ti-magnetite and platy ilmenite, display strong anisotropy under crossed nicols. Recrystallized crystals show twinning parallel to (110) planes, but most of the Ti ores lack twinning as a result of aggregate recrystallization. These features are typical of the crystallization of interwoven rutile and hematite aggregates after primary ilmenite or Ti-magnetite (Ramdohr, 1975).

\section{Clayey Substance}

The predominant clay mineral is a randomly interstratified smectite-mica with a nontronite-glauconite composition (12\% total $\mathrm{Fe}$ ). The lower expandability of this mineral in the upper, more permeable part of the section is attributed to diagenesis (Holmes, this volume). A $7-\AA$ mineral, kaolinite, occurs as a minor component in Core $120-748 \mathrm{C}-69 \mathrm{R}$ and Section 120$748 \mathrm{C}-73 \mathrm{R}-6$ to Core $120-748 \mathrm{C}-79 \mathrm{R}$ and is the principal component of the red drilling chips recovered from the bottomhole assembly (BHA) below the alkali-basalt flow.

\section{Authigenic Minerals}

The common characteristics of the authigenic minerals are a nonvolcanic origin and formation in the marine or shallow 
subsurface environment. Authigenic pyrite was previously described in the opaque mineral assemblage.

\section{Glauconite Pellets}

The glauconite pellets can be classified into four groups, each distinct in optical, morphological, and chemical properties. The rarest form of glauconite pellets (only a few grains) is light green to yellow green pleochroic with high birefringence and parallel cleavage. This variety has a mica optical quality and resembles the accordion type of Odin (1972) and Odin and Lamboy (1988). Some grains are stubby and barrel shaped; others are irregularly intergrown with spongy opaque material. Another variety displays distinct light green to bluish green pleochroism, lower birefringence, and celadonite/glauconite optical characteristics.

Most of the glauconite pellets (Plate 2, Fig. 2) have two distinct colors and two distinct morphologies: (1) dark green to brown colors and (2) smooth, oval-to-round shapes to blocky, radially cracked shapes. All transitions between these two end-member colors and morphologies are possible. Some grains have a dark green core, some with internal pyrite specks. The dark green core grades laterally into a brown rim with no pyrite (Plate 2, Fig. 2). The reverse is also seen, in which brown cores grade into green rims. Bright green rims, which enclose older brown grains, indicate new glauconite formation, possibly after reworking. Some of the fresher looking green grains are internal molds of foraminifer or other microfossil tests, bryozoan zooecia, and sponge spicules. The most abundant morphology appears to be that of fecal pellets. Some blocky and perfectly round morphologies resemble small lithic clasts and teardrop-shaped glass shards. Light brown to olive brown glauconite pellets have a platy to blocky glass shard morphology (Plate 2, Fig. 4) and are thought to be derived from vesicle-free sideromelane shards.

The microfabrics of the glauconite pellets show that they are a mixture of tiny, vermiform minerals. Zeolite and hematite also seem to be interwoven within the glauconite pellets. The pyrite interpositions are typical for green $\mathrm{Fe}$ - and $\mathrm{K}$-rich glauconite pellets and are distinctly missing in the brown $\mathrm{Al}$-rich and $\mathrm{K}$-poor glauconite pellets.

In summary, the four types of glauconite pellets are as follows:

1. accordion-type with light mica optical properties;

2 . blue green, strongly pleochroic with optical properties similar to celadonite/glauconite;

3. grass green to bright green glauconite pellets, composed of a mixture of vermiform clay minerals, possibly interwoven with zeolite, some of which are coated with pyritized fossil casts;

4. brown pellets that always lack the pyrite intergrowth but instead have $\mathrm{Fe}$ oxide/hydroxide fibers.

There is a continuous color spectrum from dark green to olive brown and deep brown to light brown and a continuous morphologic spectrum from perfectly round to angular and blocky. Most of the pellets are round to oval and smooth, and they range in size from 30 to $350 \mu \mathrm{m}$, whereas about $10 \%$ of the glauconite pellets have blocky outlines and display radial cracks. The substratum for glauconite deposition includes carbonate fossil debris, fecal pellets, and such volcanogenic components as glass shards, mica flakes, and lithic clasts. In general, at least two generations of glauconite formation have occurred.

\section{Carbonate}

The second most conspicuous neoformed mineral is light brown siderite, which forms perfectly idiomorphic rhombs as
Table 3. Chemical composition of organic phosphate debris, Hole 748C.

\begin{tabular}{llllllll}
\hline $\begin{array}{c}\text { Core, section, } \\
\text { interval }(\mathrm{cm})\end{array}$ & $\mathrm{Na}_{2} \mathrm{O}$ & $\mathrm{P}_{2} \mathrm{O}_{5}$ & $\mathrm{MgO}$ & $\mathrm{FeO}$ & $\mathrm{CaO}$ & $\mathrm{Sum}$ & Mineral \\
\hline $120-748 \mathrm{C}-$ & & & & & & & \\
$56 \mathrm{R}-2,137-144$ & 1.21 & 32.54 & 0.13 & 0.35 & 47.31 & 81.54 & Phosphate \\
$79 \mathrm{R}-4,35-37$ & 1.01 & 30.87 & 0.11 & 0.57 & 50.00 & 82.56 & Phosphate \\
& 1.17 & 30.29 & 0.09 & 0.51 & 48.66 & 80.72 & Phosphate \\
\hline
\end{tabular}

Note: Chemical composition given in weight percent.

large as $160 \mu \mathrm{m}$ in diameter. Siderite occurs predominantly in the sparsely fossiliferous Subunit IIIB. Smaller, round, Fespotted siderite concretions, $<60 \mu \mathrm{m}$ in diameter, are abundant in clay rip-up clasts, which lack glauconite but bear appreciable neoformed framboidal pyrite and dark carbonaceous matter. Sparry calcite is the dominant mineral filling cracks and interstices in Subunit IIIB. It also coats lithic clasts in conglomeratic Subunit IIIC. Carbonate cement is predominant in Subunit IIIB, whereas siliceous cement (chalcedony) is abundant in Subunit IIIA.

\section{Zeolite and Silica Varieties}

The silica component forms clear, locally perlitelike, cracked vein and pore fillings in Subunit IIIA and occurs as fibrous chalcedony to quartz. It also replaces fossil molds that may include pyrite rhombs. Between 742 and $845 \mathrm{mbsf}$ in Subunit IIIB, zeolite bundles (clinoptilolite) form a minor cement.

\section{Detrital Biogenic Material}

Biogenic material (calcareous and siliceous fossils) will not be treated in detail here (see the paleontology reports in this volume), but we do offer the following observations on phosphatic matter. Shark and mosasaur teeth, bits of bones and fish scales, and other material (Schlich, Wise, et al., 1990) appear brown to gray and are nearly isotropic or show undulatory extinction. The brown phosphatic matter is somewhat more abundant in Subunit IIIA. Its chemical composition as determined by microprobe (Table 3 ) is that of hydroxyl apatite with some appetite for $\mathrm{Na}, \mathrm{Fe}$, and $\mathrm{Mg}$. Neither $\mathrm{F}$ nor $\mathrm{Cl}$ was detected by EDX methods.

Lignite and pyritized wood fragments occur from $816 \mathrm{mbsf}$ downward (see Francis, this volume) and, together with kaolinite, indicate landbased sources. In summary, biogenic debris is most abundant in Subunit IIIA.

\section{X-ray Diffraction}

The glauconite pellets fall into two mineral groups, which coincide with the lithologic subdivisions. In lithologic Subunit IIIA, the pellets are composed of randomly interstratified glauconite-smectite with $<20 \%-40 \%$ expandable layers. In lithologic Subunit IIIB, the pellets are composed of randomly interstratified glauconite-smectite with $40 \%$ to more than $80 \%$ expandable layers or are of mixed mineral composition.

The three diffraction peaks most characteristic of glauconite are at $10.1,4.53$, and $2.587 \AA$ (Bailey, 1980). The latter two peaks are present in all unoriented samples examined (Fig. 6) but vary significantly in shape. In samples from lithologic Subunit IIIA, the peaks are well defined and symmetrical. In samples from lithologic Subunit IIIB, the peaks are broad and asymmetrical, indicating poorer crystallinity in these samples. The $10-\AA$ peak is broad, poorly defined, or nonexistent in all unoriented samples. Oriented samples show the $10-\AA$ peak clearly (Fig. 7). A "tail" appears on the low-angle side in all samples, indicating pervasive interlay- 
a. CORE $120-748 C-27 R$ $\begin{array}{lllll}4.35 & 3.63 & 3.09 & 2.67 & 2.59\end{array}$
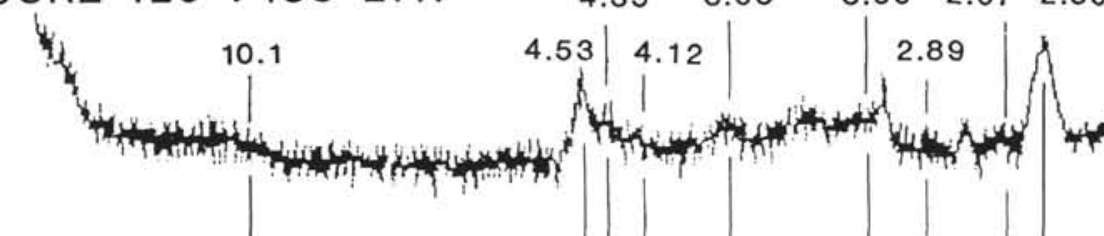

b. CORE-120-748C-56R

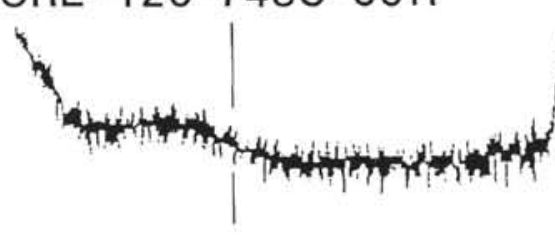

c. CORE $120-748 \mathrm{C}-62 \mathrm{R}$

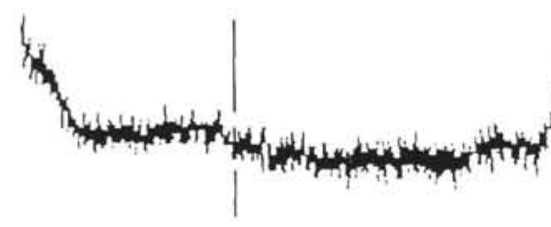

d. CORE $120-748 \mathrm{C}-68 \mathrm{R}$

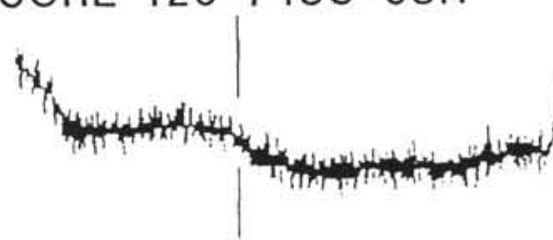

e. CORE 120-748C-69R

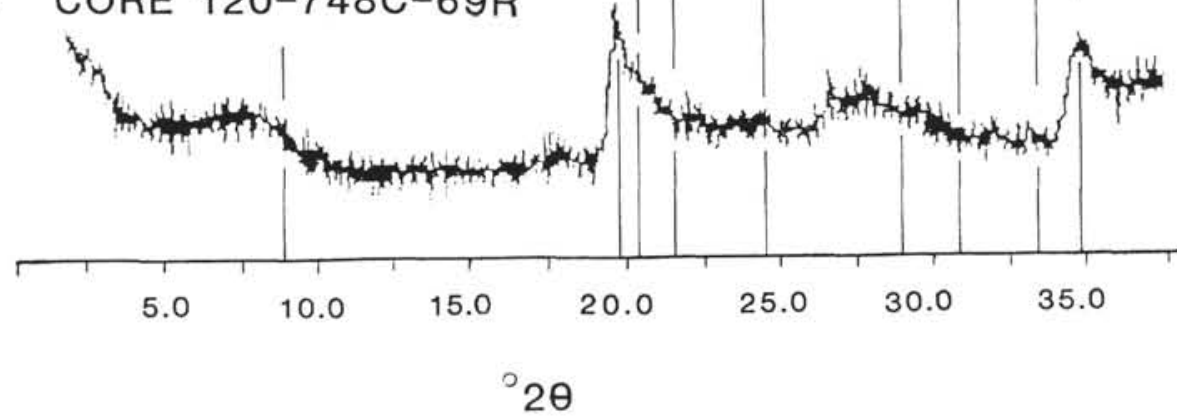

Figure 6. X-ray diffractogram of unoriented glauconite pellets. Only the diagnostic peaks for glauconite are labeled.

ering with smectite. The spacing varies from 10.3 to $10.4 \AA$ in the Subunit IIIA samples (Fig. 7), but is greater (10.5 to 12.6 $\AA$ ) in the Subunit IIIB samples. In interlayered minerals, the (001) peak shift between $10 \AA$ of mica and $15 \AA$ of smectite depends on which component is most abundant (Reynolds, 1980). The Subunit IIIA glauconite pellets have peaks closer to glauconite at $10 \AA$, indicating a greater proportion of micaceous layers than in Subunit IIIB. Well-ordered glauconite should have peaks at 3.09 and $3.63 \AA$ (Bentor and Kastner, 1965), but the 3.09- $\AA$ peak is lacking in all samples. The 3.63- $\AA$ peak is present in a few samples, but is broad and ill defined (Fig. 6).

The 10-A peak splits into two peaks upon glycolation (Fig. 8) for all samples. One peak is near $9 \AA$ and the other near $17 \AA$. Two peaks rather than one intermediate peak in samples treated with ethylene glycol indicate that interstratification is random rather than ordered (Eslinger and Pevear, 1988). In Subunit IIIB, the proportion of expandable layers is from $40 \%$ to more than $80 \%$, and expandability generally increases downhole. The pellets from Core 120-748C-73R are composed of a mixture of smectite and kaolinite.

\section{Silica}

Silica cement fills voids, replaces fossil carbonate, rarely replaces the matrix, and represents a spectrum of mineral compositions ranging from poorly to more crystalline opal-CT to quartz (Jones and Segnit, 1971). No systematic relationship exists between the silica mineralogy and depth (Fig. 9). Opal-CT was detected by XRD in most samples from Cores $120-748 C-27 R$ to $-63 R$. Samples from Cores $120-748 \mathrm{C}-40 \mathrm{R}$ and $-46 \mathrm{R}$ represent the poorly crystalline variety of silica (Fig. 10), which has a broad peak between 


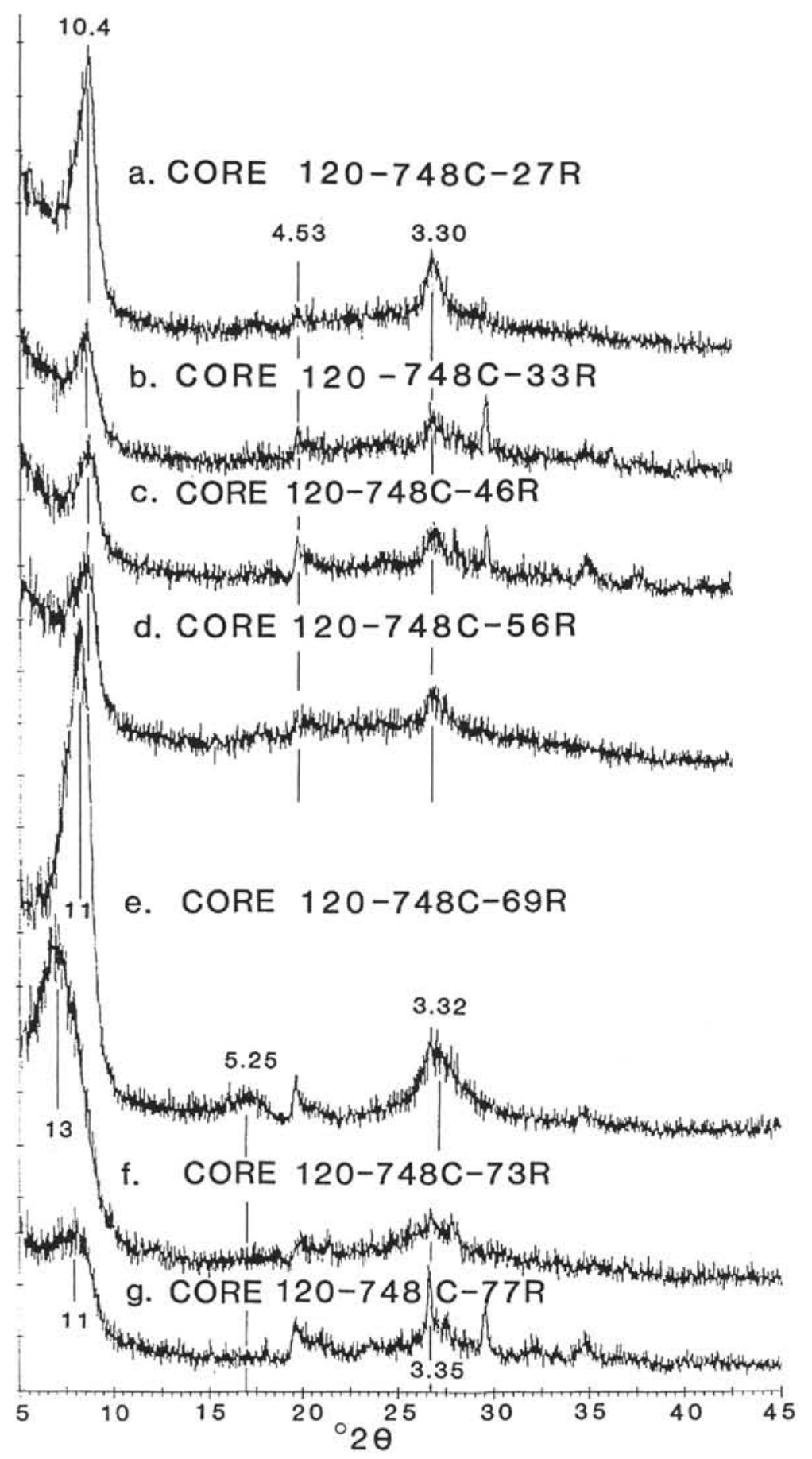

Figure 7. X-ray diffractogram of ground, oriented, untreated glauconite pellets.

$15^{\circ}$ and $25^{\circ} 2 \theta$ and a small peak at $4.1 \AA$. Samples from Cores $120-748 C-36 R$ and $-47 R$ represent the well-crystallized variety of silica (Fig. 11), with well-developed peaks at 4.1, 4.3, and $2.5 \AA$. The silica in Cores $120-748 \mathrm{C}-56 \mathrm{R}$ and $-64 \mathrm{R}$ is present as quartz, as indicated by a peak at $3.3 \AA$ (Fig. 12). The $3.3-\AA$ peak was detected in samples from Cores 120 $748 \mathrm{C}-27 \mathrm{R}$ to $-79 \mathrm{R}$, excluding most of the samples from between Cores $120-748 \mathrm{C}-30 \mathrm{R}$ and $-63 \mathrm{R}$. It is difficult to distinguish poorly from more crystalline opal-CT in thin section. The quartz detected by XRD is probably a result of detrital quartz grains.

\section{Zeolite}

The zeolite is clinoptilolite, based on the presence of peaks at 9.0, 3.9, and $2.97 \AA$ (Fig. 12) and the survival of the 9.0- $\AA$ peak after heating to $450^{\circ} \mathrm{C}$ overnight (Mumpton, 1960). It was detected in sand-size through $<0.5-\mu \mathrm{m}$ fractions. Clinoptilolite is present in Cores $120-748 \mathrm{C}-27 \mathrm{R}$ to $-73 \mathrm{R}$, excluding Cores 120 748C-50R, -52R, -54R, and -69R (Fig. 9).

\section{Clay}

The dominant clay mineral is similar to that of the glauconite pellets, a randomly interstratified smectite-glauconite, but 


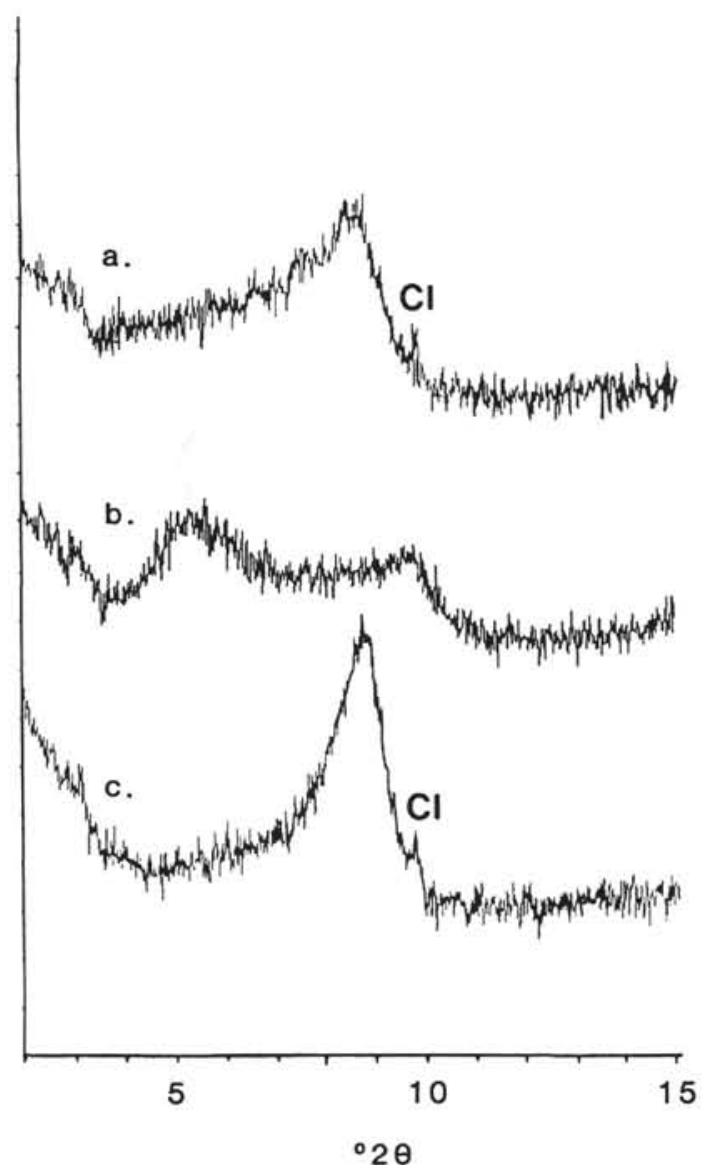

Figure 8. Magnetically susceptible fraction of Sample 120-748C$65 \mathrm{R}-1,58-59 \mathrm{~cm}$, oriented and ground. $\mathrm{Cl}=$ clinoptilolite. A. Untreated. Large peak with a slope to higher d-spacings is interlayered smectite-mica (nontronite-glauconite). B. Treated with ethylene glycol at $65^{\circ} \mathrm{C}$ overnight. Principal peak of the interlayered mineral has split into two peaks, indicating that the interlayering is random. C. Heated to $350^{\circ} \mathrm{C}$ for $3 \mathrm{hr}$.

generally with more smectite layers than the glauconite pellets (see Holmes, this volume). Expandability ranges from $49 \%$ to $70 \%$ and increases downhole. Kaolinite is a small component of the samples from Core $120-748 \mathrm{C}-73 \mathrm{R}$ to the base of the recovered section, Core 120-748C-79R (Fig. 9). Red drilling chips recovered from the BHA are composed dominantly of kaolinite and less of goethite, without interstratified minerals. This assemblage is identical to that of the Albian nonmarine volcanogenic epiclastic sediment at Site 750 (Holmes, this volume).

\section{Chemistry}

The bulk-rock chemistry (Table 4), and especially the trace elements $\mathrm{Cr}$ (indicative of the type and volume of eroded source rocks), $\mathrm{Zr}$ (indicative of continuous or periodic erosion and reworking of the alkali-basalt source rocks), and $\mathrm{Sr}$ or $\mathrm{CO}_{2}$ (as a measure of marine carbonate input), allow for qualitative and quantitative modeling of the terrestrial and marine sources during formation of the glauconitic sediment. The role of the different glauconite pellet types as a sink for $\mathrm{K}, \mathrm{Fe}$, or $\mathrm{Al}$ and other elements is emphasized by the mineral chemistry (Table 5).

\section{Bulk-Rock Chemistry}

The major and trace element compositions of the analyzed samples confirm the macroscopic subdivision of this

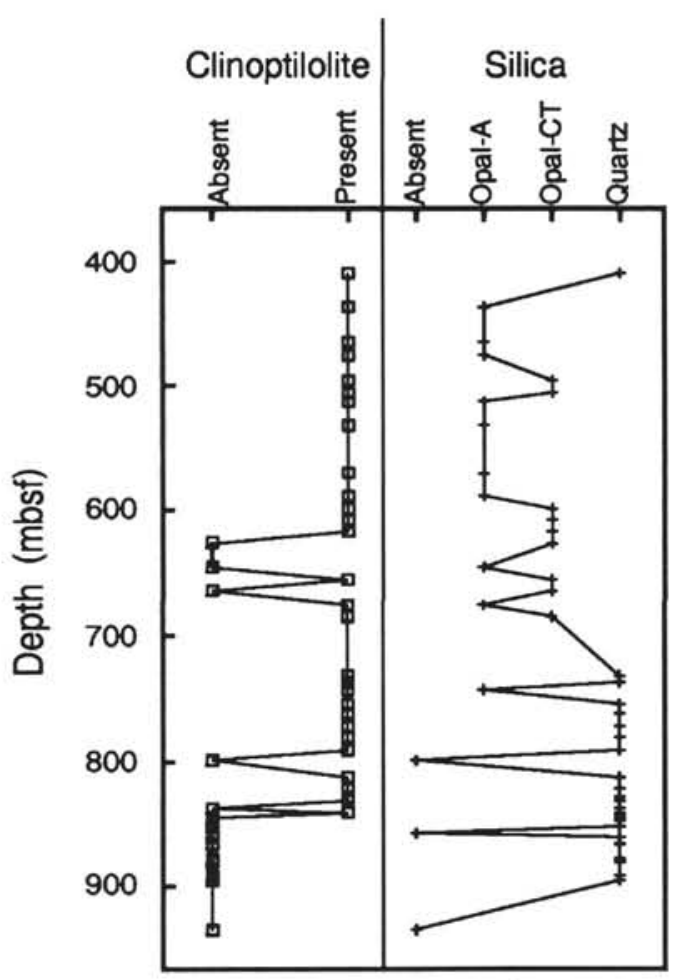

Figure 9. Occurrence of clinoptilolite and forms of silica in Cretaceous sediment of Hole $748 \mathrm{C}$.

sediment into three lithologic subunits (Fig. 13 and Table 4). Subunit IIIA (four samples) is characterized by high concentrations of $\mathrm{CaO}(5.01 \%-40.86 \%), \mathrm{CO}_{2}(6.04 \%-34.09 \%), \mathrm{P}_{2} \mathrm{O}_{5}$ $(0.59 \%-1.12 \%)$, and total carbonate and low concentrations of $\mathrm{Fe}_{2} \mathrm{O}_{3}(2.80 \%-14.46 \%), \mathrm{Al}_{2} \mathrm{O}_{3}(7.45 \%-1.53 \%), \mathrm{TiO}_{2}(0.19 \%$ $0.98 \%), \mathrm{K}_{2} \mathrm{O}(0.59 \%-2.8 \%)$, and $\mathrm{Na}_{2} \mathrm{O}(0.75 \%-1.38 \%)$ (Table 4). Compared with Subunits IIIB and IIIC, the trace elements $\mathrm{Cr}, \mathrm{Zr}, \mathrm{Nb}, \mathrm{Rb}$, and $\mathrm{V}$ are less abundant in Subunit IIIA, whereas $\mathrm{Sr}$ and $\mathrm{Y}$ have somewhat higher concentrations (Fig. 13 and Table 4). Subunit IIIB (15 samples) has high concentrations of $\mathrm{Fe}_{2} \mathrm{O}_{3}(12.61 \%-15.84 \%), \mathrm{H}_{2} \mathrm{O}(4.99 \%$ $7.55 \%)$, and $\mathrm{K}_{2} \mathrm{O}(1.69 \%-2.83 \%)$ and a low concentration of $\mathrm{P}_{2} \mathrm{O}_{5}(0.10 \%-0.23 \%)$, but high concentrations of $\mathrm{Cr}(290-725$ ppm; Fig. 13), Zn (65-193 ppm), and V (130-284 ppm). The basal conglomerate (Subunit IIIC, two samples) has the highest concentrations of $\mathrm{Ba}$ (1441 and $1701 \mathrm{ppm}), \mathrm{Sr}(883$ and $951 \mathrm{ppm}), \mathrm{TiO}_{2}(2.81 \%$ and $3.34 \%), \mathrm{Al}_{2} \mathrm{O}_{3}(16.29 \%$ and $17.96 \%), \mathrm{P}_{2} \mathrm{O}_{5}(1.06 \%$ and $1.37 \%), \mathrm{Zr}(402$ and $502 \mathrm{ppm}), \mathrm{Nb}$ ( 81 and $102 \mathrm{ppm}), \mathrm{Y}$ (36 and $45 \mathrm{ppm})$, and $\mathrm{Ni}$ (144 and 172 ppm) (Fig. 13 and Table 4).

The observed variations in major and trace elements (Fig. 13 and Table 4) can be explained as follows: the basal conglomerate bears alkali-basalt pebbles and nearly matches the composition of the underlying alkali-basalt flow (Salters et al., this volume). This explains the high incompatible element concentrations ( $\mathrm{Ti}, \mathrm{Zr}, \mathrm{Nb}, \mathrm{Ba}, \mathrm{Sr}, \mathrm{Y}$, and $\mathrm{P}$ ).

The enrichment of Subunit IIIB in Fe, Cr (Fig. 13), V, and $\mathrm{Zn}$ and partly in $\mathrm{Ti}$ is due to the mechanical admixture of robust $\mathrm{Cr}$-, $\mathrm{Fe}-$, and Ti-bearing ore minerals. To some extent, $\mathrm{Al}, \mathrm{Fe}$, and $\mathrm{V}(?)$ as well as $\mathrm{Cr}$ and $\mathrm{Ti}$ were absorbed by glauconite pellets and probably other clay minerals. The formation of green glauconite pellets provides a sink for $\mathrm{K}$, $\mathrm{Rb}, \mathrm{Fe}$, and $\mathrm{Mg}$ and explains the enrichment in these elements in Subunit IIIB. Siderite is another Fe-incorporating mineral, as is pyrite. 
a. Sample $120-748 \mathrm{C}-40 \mathrm{R}-1,55-57 \mathrm{~cm}$.
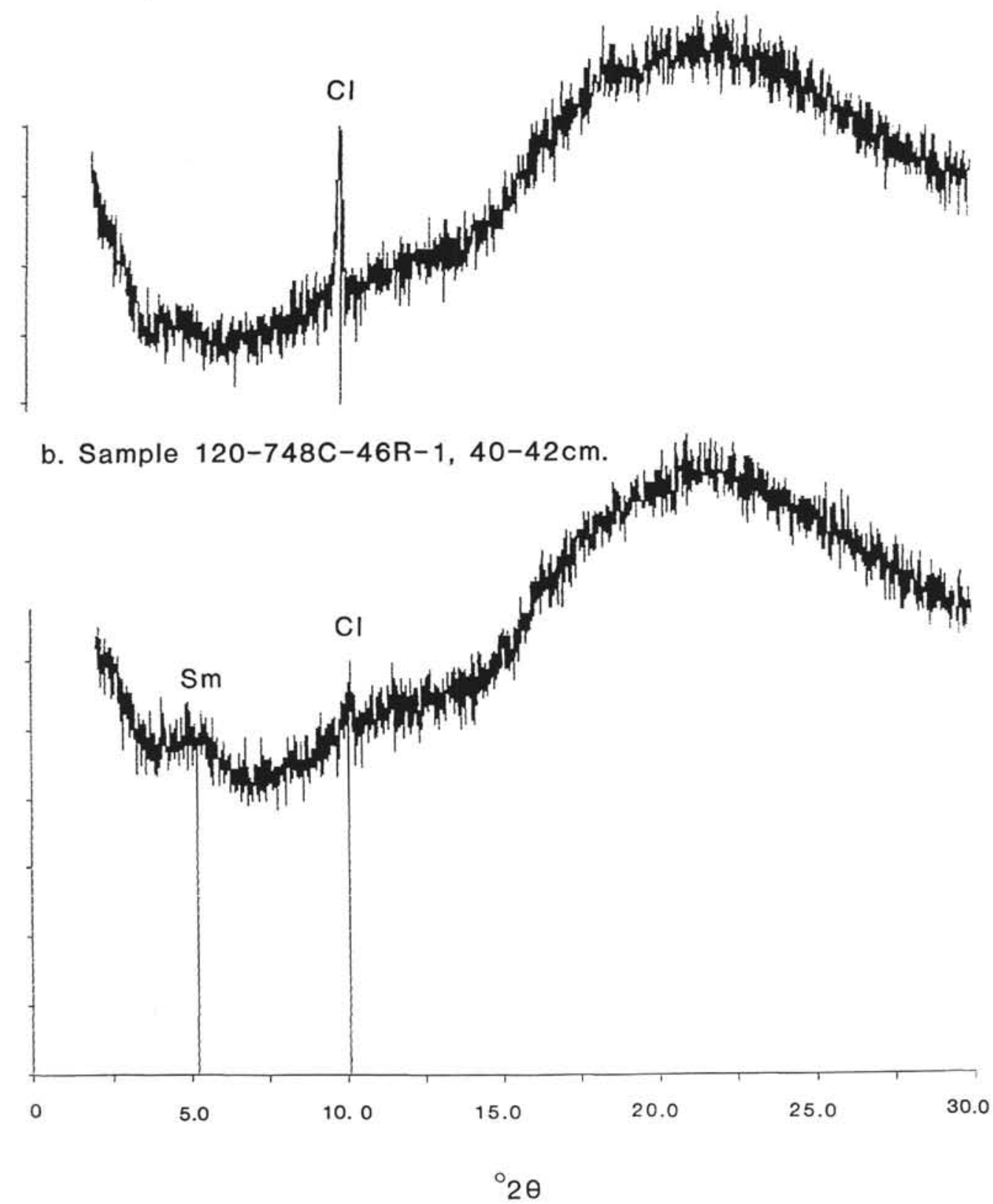

Figure 10. X-ray diffractograms of poorly crystalline silica (opal-A). $\mathrm{Sm}=$ smectite and $\mathrm{Cl}=$ clinoptilolite.

Subunit IIIA had the highest input of biogenic carbonate and phosphate debris, which explains the high $\mathrm{CaO}, \mathrm{CO}_{2}$, $\mathrm{P}_{2} \mathrm{O}_{5}$, and $\mathrm{Sr}$ concentrations. The decrease in clayey matter, glauconite pellets, and detrital opaque phases is evident from the low concentrations of $\mathrm{Al}, \mathrm{Fe}, \mathrm{Ti}, \mathrm{Cr}$, and alkalis. The rather high $\mathrm{Y}$ values, however, are surprising and cannot be explained.

The bulk-rock chemistry can be correlated with the macroscopic and microscopic findings. The particularly steady dilution of the incompatible and immobile elements $\mathrm{Zr}, \mathrm{Nb}$, and $\mathrm{Ti}$ derived from the alkali-basalt shows the waning input from that source, which is inferred to have been an oceanic island. The $\mathrm{Cr}$ enrichment especially serves as an indicator for ultramafic source rocks such as peridotites.

\section{Mineral Chemistry}

\section{Glauconite Pellets}

The glauconite pellets consist of randomly interstratified glauconite-smectite and are the major sink for $\mathrm{K}, \mathrm{Fe}, \mathrm{Al}$, and some $\mathrm{Si}$. Optical and XRD investigations revealed that some glauconite pellets have additional zeolite (high $\mathrm{Si}, \mathrm{Al}$, and $\mathrm{Ca}$ concentrations of the glauconitic grains). To check the compositional range we analyzed individual grains of each type with the microprobe (EMP). The results (Fig. 14 and Table 5) show the wide range in element composition of the various types and the interdependence of color and chemistry, and thus the dependance on redox conditions. The EMP analysis of individual grains is at least as useful for glauconite characterization as are bulk-sample XRF analyses 


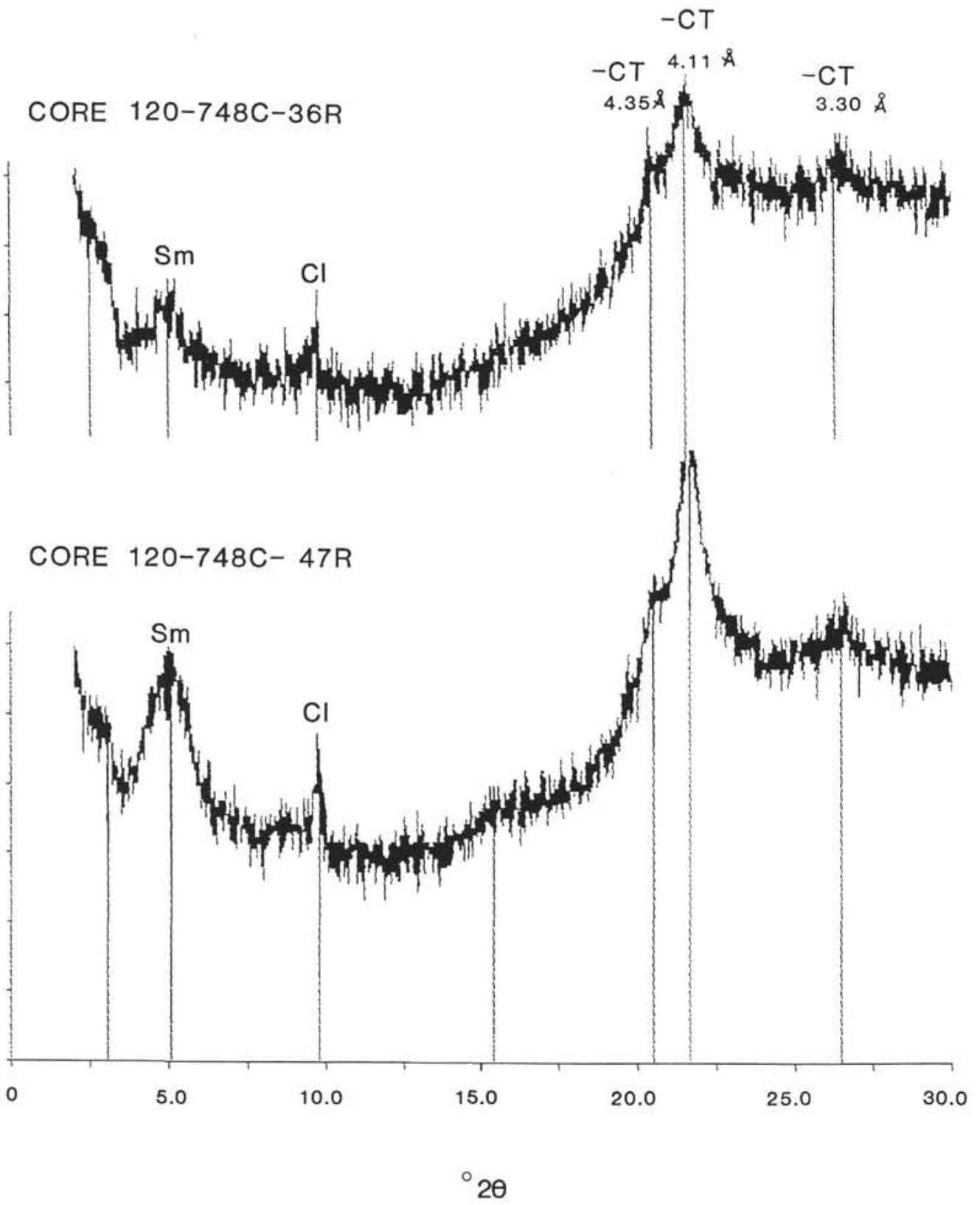

Figure 11. X-ray diffractograms of opal-CT. $\mathrm{Sm}=$ smectite and $\mathrm{Cl}=$ clinoptilolite.

(which are even more mixtures of mixtures), in contrast to Odin et al. (1988a) and Odin and Fullagar (1988), who considered bulk-sample analyses combined with XRD as meaningful for chemical investigations of glauconite pellets.

The accordion-type glauconite pellets are low in $\mathrm{K}_{2} \mathrm{O}$ (2.70\% and $3.26 \%$ ). The $\mathrm{MgO}$ and $\mathrm{Al}_{2} \mathrm{O}_{3}$ concentrations are more typical of illites/montmorillonites. The blue green glauconite pellets are distinguished by their high $\mathrm{K}_{2} \mathrm{O}$ concentrations, between $7.10 \%$ and $10.13 \%$ (Fig. 14). They also have the highest $\mathrm{MgO}$ (as much as $6.58 \%$ ) and lowest $\mathrm{Al}_{2} \mathrm{O}_{3}$ (2.68\% to $10.1 \%$ ) concentrations (Fig. 14) and are low in impurities such as $\mathrm{CaO}, \mathrm{TiO}_{2}, \mathrm{Cr}_{2} \mathrm{O}_{3}, \mathrm{MnO}, \mathrm{P}_{2} \mathrm{O}_{5}$, and $\mathrm{Na}_{2} \mathrm{O}$ (total $<0.5 \%$ ). This composition is closest to that of published glauconite/celadonite mica data (Newman and Brown, 1987). Bright green glauconite pellets have lower $\mathrm{K}_{2} \mathrm{O}$
$(<7.2 \%)$, reflecting the pervasive expandable mineral interstratification observed with $\mathrm{XRD}$. They also have lower $\mathrm{MgO}(<4.8 \%)$ and higher $\mathrm{Al}_{2} \mathrm{O}_{3}(<14.4 \%)$ concentrations than the blue green glauconite/celadonite type. The olive brown glauconite pellets have distinctly low $\mathrm{K}_{2} \mathrm{O}(<3.8 \%)$ and high $\mathrm{Al}_{2} \mathrm{O}_{3}$ (>14\% to as much as $28 \%$; Fig. 14) concentrations. Consequently, they are assumed to be more interstratified with smectite than the green pellets. Impurities of $\mathrm{TiO}_{2}$ (as much as $4.6 \%$, mostly at about $0.4 \%-0.9 \%$ ) and $\mathrm{Cr}_{2} \mathrm{O}_{3}$ (as much as $0.14 \%$ ) are associated with deep brown grains but may occur with all glauconite pellet types. The $\mathrm{Fe}$ and $\mathrm{Al}$ levels are compatible with results of studies of other brown glauconitic pellets (Newman and Brown, 1987), but with lower $\mathrm{K}_{2} \mathrm{O}$ concentrations. Impurities such as $\mathrm{CaO}$ and $\mathrm{Na}_{2} \mathrm{O}$, as well as excess $\mathrm{SiO}_{2}$, are the result hypothetically of (1) interwoven zeolite and silica varieties or (2) a greater 


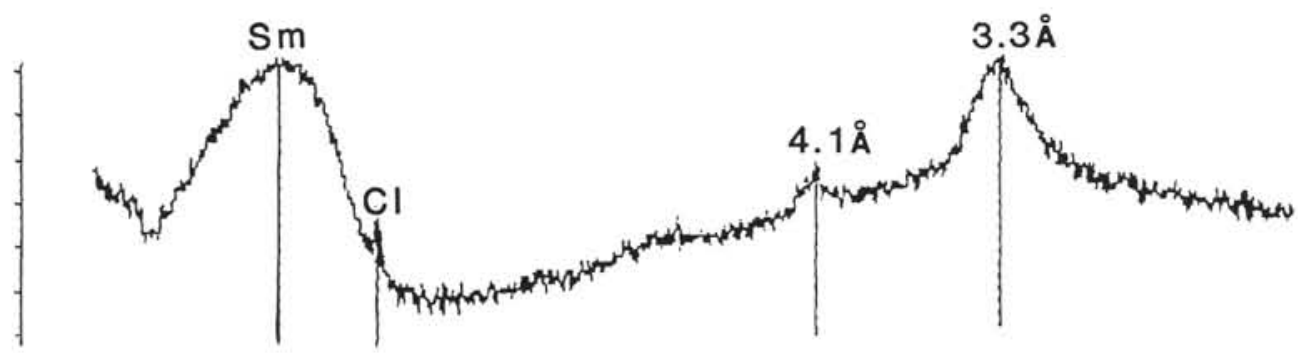

b. Sample $120-748 \mathrm{C}-64 \mathrm{R}-2,93-94 \mathrm{~cm}$.

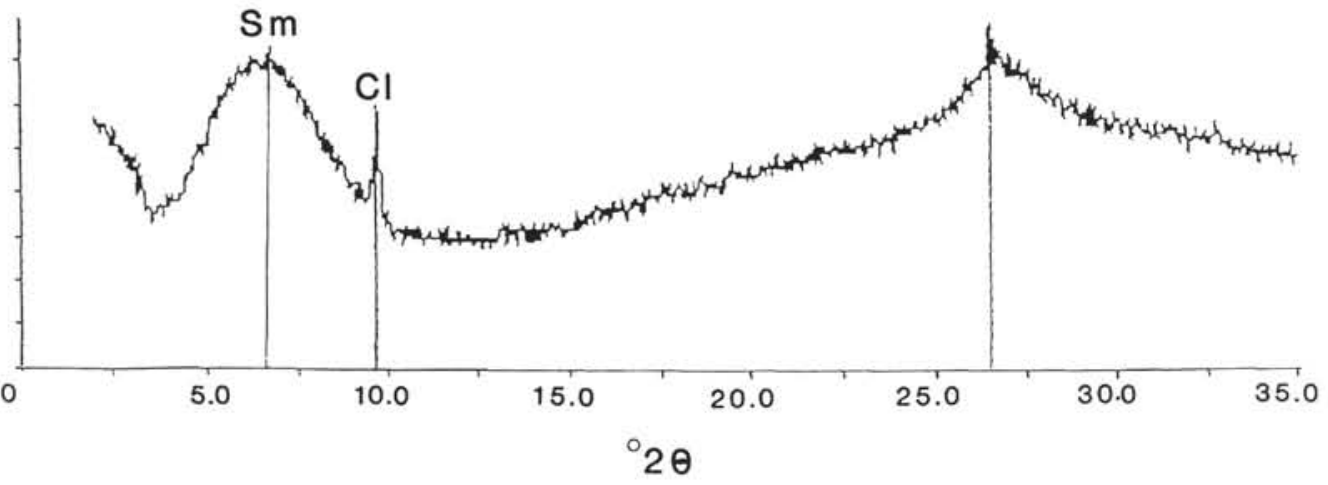

Figure 12. X-ray diffractograms of quartz at $3.3 \AA$, smectite (Sm), and clinoptilolite (Cl).

proportion of expandable layers. Light brown glauconite pellets are always rich in $\mathrm{Al}_{2} \mathrm{O}_{3}$. They are also high in $\mathrm{SiO}_{2}$, $\mathrm{Na}_{2} \mathrm{O}$, and $\mathrm{CaO}$ and poor in $\mathrm{K}_{2} \mathrm{O}$ and $\mathrm{FeO}$ (Fig. 14). They are thought to represent the altered, oxidized, and hydrated remnants of volcanogenic glasses or to have formed in proximity to dissolving plagioclase grains.

The microscopically observed green to brown suite of glauconite pellets can be perfectly correlated to variations in $\mathrm{K}_{2} \mathrm{O}, \mathrm{MgO}, \mathrm{Al}_{2} \mathrm{O}_{3}$, and $\mathrm{FeO}$. The distinct correlations between color and chemistry are well illustrated in Figure 14.

Results from the atomic absorption analysis of the exchangeable ions from the glauconite pellets reveal no $\mathrm{Cr}$. The $\mathrm{NH}_{4}^{+}$-exchanged glauconite observed in SEM has traces of $\mathrm{Cr}$ (see the microprobe data) indicated by EDX. The $\mathrm{Cr}$ may be present within the crystal lattice and not on the exchange complex. $\mathrm{Cr}$ is similar in size and charge to $\mathrm{Fe}$, so it may be assumed that $\mathrm{Cr}$ proxies for $\mathrm{Fe}$ in the octahedral layer. Alternatively, $\mathrm{Cr}$ may be present as a precipitate in interlayer space. Analysis by EDX reveals that the clay is richer in $\mathrm{Si}$ than are the glauconite pellets (average $57 \%$ vs. $52 \%$ ). The samples analyzed were rich in $\mathrm{Ti}$, from $2.6 \%$ to $4.9 \%$. Mg was not detected in the clay samples, but trace amounts of $\mathrm{Cr}$ were. Samples from Subunit IIIA, which have more interstratified glauconite layers, have higher $\mathrm{K}$ contents than samples from Subunit IIIB ( $8.7 \%$ vs. $6.2 \%)$.

\section{Cr-Spinel and Ilmenite/Magnetite}

$\mathrm{Cr}$-spinel has $\mathrm{Cr}_{2} \mathrm{O}_{3}$ concentrations between $30.7 \%$ and $43.8 \%$ and bears $\mathrm{Fe}, \mathrm{Al}, \mathrm{Mg}$, Ti, and $\mathrm{Mn}$ (Table 6). The most $\mathrm{Cr}$-rich spinels have the highest $\mathrm{MgO}$ and $\mathrm{TiO}_{2}$ and lowest $\mathrm{Al}_{2} \mathrm{O}_{3}, \mathrm{FeO}$, and $\mathrm{MnO}$ concentrations. The $\mathrm{Cr}$-spinels from the alkali basalt and the glauconitic sediment are similar in composition. They probably have the same origin and are thought to have been derived from a Cr-spinel-bearing peridotite source.

Ilmenite, or its respective alteration/breakdown products consisting of $\mathrm{Ti}$ and $\mathrm{Fe}$ ores such as rutile, hematite, etc., occurs as opaque grains, has $\mathrm{TiO}_{2}$ concentrations of $48 \%-51 \%$, and contains $\mathrm{FeO}$ between $47 \%$ and $49 \%$ (Table 6). Pure rutile was also identified (Table 6). The opaque Ti phases have low oxide sums because they are mixtures of several ore mineral species, some of which may contain appreciable $\mathrm{V}$ and even $\mathrm{Nb}$ or $\mathrm{Ta}$. In addition, the surfaces of these Ti minerals are not planar and smooth but are ragged and heterogeneous, which is a technical reason for low oxide sums. Nevertheless, the analyses give a good estimate of the bulk composition of these opaque grains and lead to the conclusion that ilmenite-magnetite/hematite ores were the precursors of these detrital ores.

\section{Quartz and Plagioclase Quartz}

Quartz was used as an internal standard. The oxide sums at $15 \mathrm{kV} / 14 \mathrm{nA}$ were consistently at a confidence level of $100 \% \pm$ 
Table 4. Bulk-rock chemistry of selected samples, Hole $748 \mathrm{C}$.

\begin{tabular}{|c|c|c|c|c|c|c|c|c|c|c|}
\hline $\begin{array}{l}\text { Core, section, } \\
\text { interval }(\mathrm{cm})\end{array}$ & $\mathrm{Na}_{2} \mathrm{O}$ & $\mathrm{SiO}_{2}$ & $\mathrm{Al}_{2} \mathrm{O}_{3}$ & $\mathrm{MgO}$ & $\mathrm{FeO}$ & $\mathrm{Cr}_{2} \mathrm{O}_{3}$ & $\mathrm{~K}_{2} \mathrm{O}$ & $\mathrm{TiO}_{2}$ & $\mathrm{CaO}$ & Sum \\
\hline \multicolumn{11}{|l|}{$120-748 \mathrm{C}-$} \\
\hline \multicolumn{11}{|l|}{$63 R-1,103-105$} \\
\hline blue green & 0.16 & 54.36 & 3.44 & 6.58 & 17.26 & 0.01 & 9.37 & 0.07 & 0.00 & 91.25 \\
\hline green & 0.90 & 51.12 & 10.93 & 3.21 & 17.59 & 0.09 & 4.87 & 0.12 & 0.46 & 89.29 \\
\hline deep brown & 2.08 & 54.46 & 17.36 & 3.33 & 6.85 & 0.07 & 1.28 & 2.44 & 1.99 & 89.86 \\
\hline middle brown & 1.66 & 53.76 & 12.89 & 2.76 & 15.87 & 0.04 & 2.61 & 0.15 & 0.81 & 90.55 \\
\hline green core & 0.93 & 52.52 & 12.58 & 2.58 & 16.36 & 0.02 & 5.71 & 0.15 & 0.48 & 91.33 \\
\hline green rim & 0.73 & 52.56 & 13.08 & 2.59 & 15.74 & 0.03 & 5.02 & 0.25 & 0.25 & 90.25 \\
\hline green & 0.81 & 50.75 & 8.69 & 2.58 & 21.11 & 0.08 & 6.13 & 0.29 & 0.26 & 90.70 \\
\hline grass green & 0.51 & 54.13 & 10.11 & 4.78 & 12.43 & 0.00 & 7.21 & 0.50 & 0.00 & 89.67 \\
\hline green brown & 1.27 & 53.20 & 12.70 & 2.79 & 15.93 & 0.07 & 3.33 & 0.16 & 0.81 & 90.26 \\
\hline brown & 1.69 & 53.92 & 17.12 & 2.42 & 13.13 & 0.09 & 2.20 & 0.05 & 0.82 & 91.44 \\
\hline deep brown & 1.75 & 52.78 & 15.18 & 2.71 & 10.55 & 0.14 & 1.86 & 4.61 & 1.24 & 90.82 \\
\hline green & 0.98 & 53.47 & 10.78 & 2.79 & 17.53 & 0.06 & 4.81 & 0.18 & 0.96 & 91.56 \\
\hline \multicolumn{11}{|l|}{$79 \mathrm{R}-5,22-24$} \\
\hline green & 0.56 & 52.08 & 9.76 & 3.14 & 19.77 & 0.05 & 6.18 & 0.09 & 0.23 & 91.86 \\
\hline green brown & 0.83 & 49.96 & 20.24 & 2.46 & 9.61 & 0.04 & 2.10 & 0.09 & 0.76 & 86.09 \\
\hline brown & 0.79 & 51.45 & 10.32 & 3.05 & 19.97 & 0.08 & 4.76 & 0.11 & 0.50 & 91.03 \\
\hline brown & 1.45 & 54.16 & 25.04 & 2.49 & 3.14 & 0.07 & 0.30 & 0.07 & 1.07 & 87.79 \\
\hline green margin & 1.24 & 51.06 & 13.17 & 3.07 & 18.36 & 0.02 & 3.09 & 0.07 & 0.89 & 90.97 \\
\hline brown core & 1.46 & 51.70 & 12.80 & 3.59 & 17.84 & 0.07 & 3.11 & 0.11 & 0.86 & 91.54 \\
\hline pale brown & 2.32 & 55.51 & 24.70 & 2.51 & 3.15 & 0.05 & 0.59 & 0.07 & 1.18 & 90.08 \\
\hline pale brown & 2.06 & 55.75 & 24.28 & 2.57 & 3.29 & 0.04 & 0.56 & 0.13 & 1.05 & 89.73 \\
\hline pale brown & 1.98 & 55.67 & 25.10 & 2.49 & 2.93 & 0.00 & 0.56 & 0.23 & 1.16 & 90.12 \\
\hline green & 0.51 & 50.66 & 10.24 & 2.68 & 20.78 & 0.00 & 6.54 & 0.04 & 0.24 & 91.69 \\
\hline grass green & 0.23 & 48.89 & 10.28 & 2.91 & 19.41 & 0.00 & 6.21 & 0.13 & 0.16 & 88.22 \\
\hline $\begin{array}{c}\text { sheet silicate in } \\
\text { basalt pebble }\end{array}$ & 0.73 & 50.10 & 9.98 & 2.85 & 20.41 & 0.00 & 5.88 & 0.16 & 0.58 & 90.69 \\
\hline brown & 1.86 & 56.37 & 18.73 & 3.75 & 8.10 & 0.11 & 0.76 & 0.91 & 1.27 & 91.86 \\
\hline brown & 1.79 & 54.92 & 17.96 & 3.26 & 9.53 & & 1.87 & 0.15 & 0.78 & 90.26 \\
\hline green core & 0.60 & 51.94 & 9.66 & 3.10 & 20.39 & 0.00 & 6.03 & 0.03 & 0.29 & 92.04 \\
\hline brown margin & 0.77 & 52.34 & 10.61 & 3.43 & 18.72 & 0.00 & 5.06 & 0.24 & 0.52 & 91.69 \\
\hline brown & 1.53 & 55.53 & 21.93 & 3.49 & 5.06 & 0.02 & 0.92 & 0.41 & 0.95 & 89.84 \\
\hline olive brown & 1.00 & 53.01 & 11.06 & 3.07 & 17.47 & 0.05 & 4.85 & 0.67 & 0.43 & 91.61 \\
\hline accordeon type & 0.96 & 49.49 & 14.95 & 3.41 & 12.31 & 0.04 & 3.26 & 0.12 & 0.77 & 85.31 \\
\hline brown & 1.21 & 48.97 & 13.50 & 3.95 & 19.48 & 0.06 & 1.29 & 0.30 & 1.43 & 90.19 \\
\hline \multicolumn{11}{|l|}{$79 \mathrm{R}-4,107-109$} \\
\hline green & 0.49 & 51.42 & 10.46 & 3.12 & 18.64 & 0.07 & 6.75 & 0.10 & 0.00 & 91.05 \\
\hline green & 0.77 & 50.25 & 11.71 & 3.31 & 17.20 & 0.02 & 5.67 & 0.17 & 0.06 & 89.16 \\
\hline blue green & 0.08 & 53.42 & 2.68 & 5.75 & 19.82 & 0.01 & 10.13 & 0.00 & 0.00 & 91.89 \\
\hline brown & 1.83 & 56.61 & 18.33 & 3.61 & 7.33 & 0.12 & 1.04 & 0.05 & 0.61 & 89.53 \\
\hline & 0.41 & 48.72 & 8.96 & 2.92 & 21.31 & 0.00 & 7.73 & 0.04 & 0.00 & 90.09 \\
\hline brown & 1.48 & 51.25 & 12.21 & 3.61 & 17.44 & 0.01 & 3.66 & 0.08 & 0.45 & 90.19 \\
\hline light brown & 1.12 & 52.43 & 15.24 & 3.43 & 12.19 & 0.07 & 3.35 & 0.05 & 0.31 & 88.19 \\
\hline
\end{tabular}

Notes: Major elements given in weight percent, and trace elements in ppm.

$1 \%$ and are a reliable indicator for precision and accuracy of the analytical setup. The measurable $\mathrm{Al}_{2} \mathrm{O}_{3}$ concentrations (Table 7) might be due to incipient smectite formation (very early stage glauconitization) along microcracks. The $\mathrm{FeO}$ measured is real and might indicate (high temperature?) alteration of the source rock, most probably a rhyolite.

Plagioclases, when perfectly clear, also give reasonable analytical oxide sums (Table 7). All the feldspars analyzed have bytownitic compositions, except for one anomalous sample with anorthoclase composition and erroneously high $\mathrm{FeO}$, which probably resulted from hematite incorporation. Somewhat-altered feldspars have faint brown to red colors caused by alteration. All the plagioclases measured throughout the sequence resemble plagioclases from tholeiitic N/TMORB basalts from the Southern Kerguelen Plateau (Mehl et al., 1990). Plagioclases from the alkali basalt have the same An contents but are significantly higher in $\mathrm{K}$ (Table 7) in comparison with the plagioclases analyzed here.

\section{Carbonates}

Carbonates were analyzed to characterize the two types distinguished optically: siderite rhombs and sparry calcite cement. Siderite contains some $\mathrm{MgO}, \mathrm{CaO}$, and $\mathrm{MnO}$ (Table 8 ), which substitute for $\mathrm{FeO}$. $\mathrm{Si}$ and $\mathrm{P}$ impurities indicate the circulation of $\mathrm{P}$ - and $\mathrm{Si}$-rich fluids during siderite formation. P-rich calcite has also been analyzed in calcite fillings in basalt cracks from Site 738 (Barron, Larsen, et al., 1989). The calcite from Unit III at Site 748 has some $\mathrm{FeO}$ and $\mathrm{MnO}$ (Table 8) replacing $\mathrm{CaO}$.

\section{DISCUSSION}

\section{Sediment Sources}

Detrital Cr-spinel is the principal Cr-bearing phase responsible for the $\mathrm{Cr}$ enrichment of the glauconitic sediment. Minor but significant contributors include green $\mathrm{K}$ - and $\mathrm{Fe}$-rich glauconite pellets and clay minerals. The $\mathrm{Cr}$-spinel is compositionally similar to $\mathrm{Cr}$-spinel xenocrysts of the underlying alkali basalt, resembles $\mathrm{Cr}$-spinels from oceanic peridotite bodies (e.g., Hamlyn and Bonatti, 1980), and denotes the erosion of a peridotic source associated with alkali-basalt volcanic edifices. A likely scenario would be an alkali-basalt volcanic province with either alkali-basalt flows with as much as $\mathbf{2 0 \%}$ peridotite xenoliths or peridotic massifs piercing the 
Table 5. Microprobe analysis of discrete, varicolored glauconite pellets, Hole 748C.

\begin{tabular}{|c|c|c|c|c|c|c|c|c|c|c|}
\hline $\begin{array}{l}\text { Core, section, } \\
\text { interval }(\mathrm{cm})\end{array}$ & $\mathrm{Na}_{2} \mathrm{O}$ & $\mathrm{SiO}_{2}$ & $\mathrm{Al}_{2} \mathrm{O}_{3}$ & $\mathrm{MgO}$ & $\mathrm{FeO}$ & $\mathrm{Cr}_{2} \mathrm{O}_{3}$ & $\mathrm{~K}_{2} \mathrm{O}$ & $\mathrm{TiO}_{2}$ & $\mathrm{CaO}$ & Sum \\
\hline \multicolumn{11}{|l|}{$120-748 \mathrm{C}-$} \\
\hline \multicolumn{11}{|l|}{$79 R-4,35-37$} \\
\hline brown & 3.03 & 52.64 & 16.03 & 3.67 & 13.40 & 0.13 & 1.38 & 0.12 & 0.33 & 90.73 \\
\hline green & 0.82 & 51.07 & 14.80 & 3.00 & 12.30 & 0.04 & 3.29 & 0.25 & 0.45 & 86.02 \\
\hline green & 1.53 & 50.17 & 13.28 & 2.71 & 16.96 & 0.03 & 4.34 & 0.05 & 0.60 & 89.67 \\
\hline brown & 1.35 & 54.43 & 18.83 & 3.16 & 10.26 & 0.13 & 3.03 & 0.24 & 0.80 & 92.23 \\
\hline brown & 2.01 & 54.43 & 17.55 & 2.88 & 12.04 & 0.06 & 1.75 & 0.10 & 0.79 & 91.61 \\
\hline accordeon type & 1.38 & 53.31 & 16.09 & 3.63 & 11.32 & 0.08 & 2.70 & 0.16 & 0.47 & 89.14 \\
\hline brown & 1.51 & 53.13 & 27.97 & 2.36 & 5.38 & 0.08 & 1.01 & 0.06 & 0.75 & 92.25 \\
\hline green & 1.05 & 51.54 & 13.42 & 2.46 & 17.68 & 0.02 & 4.67 & 0.08 & 0.57 & 91.49 \\
\hline brown & 1.56 & 52.38 & 15.80 & 2.65 & 13.24 & 0.10 & 2.90 & 0.09 & 0.75 & 89.47 \\
\hline orange brown & 1.83 & 55.97 & 15.70 & 4.09 & 9.34 & 0.06 & 2.50 & 0.38 & 0.64 & 90.51 \\
\hline \multicolumn{11}{|l|}{$75 \mathrm{R}-5,50-52$} \\
\hline green & 0.41 & 52.57 & 9.90 & 2.92 & 19.32 & 0.00 & 6.51 & 0.18 & 0.00 & 91.81 \\
\hline grass green & 0.23 & 54.43 & 7.90 & 4.93 & 15.45 & 0.04 & 8.60 & 0.46 & 0.00 & 92.04 \\
\hline grass green & 0.30 & 54.91 & 8.50 & 4.88 & 14.44 & 0.07 & 8.58 & 0.44 & 0.00 & 92.12 \\
\hline brown & 1.77 & 55.37 & 14.65 & 2.90 & 13.23 & 0.20 & 1.66 & 0.13 & 0.99 & 90.90 \\
\hline olive brown & 0.60 & 51.94 & 11.36 & 2.47 & 19.75 & 0.00 & 6.28 & 0.07 & 0.27 & 92.74 \\
\hline light green & 0.91 & 52.53 & 11.78 & 2.80 & 18.57 & 0.08 & 4.80 & 0.00 & 0.56 & 92.03 \\
\hline green & 0.43 & 50.52 & 8.65 & 2.73 & 22.07 & 0.04 & 7.77 & 0.06 & 0.00 & 92.27 \\
\hline red brown & 1.83 & 54.96 & 18.47 & 3.17 & 11.34 & 0.07 & 1.54 & 0.10 & 0.86 & 92.34 \\
\hline light brown & 2.33 & 57.48 & 23.75 & 2.26 & 5.93 & 0.11 & 0.37 & 0.10 & 1.04 & 92.37 \\
\hline \multicolumn{11}{|l|}{$75 \mathrm{R}-1,36-38$} \\
\hline green & 0.87 & 52.53 & 8.59 & 3.21 & 16.19 & 0.11 & 4.70 & 0.34 & 0.10 & 86.64 \\
\hline green & 0.61 & 50.34 & 5.97 & 2.78 & 22.15 & 0.03 & 6.54 & 0.24 & 0.00 & 88.66 \\
\hline grass green & 0.49 & 53.11 & 5.91 & 5.20 & 16.14 & 0.03 & 8.67 & 0.14 & 0.00 & 89.69 \\
\hline green & 0.77 & 50.92 & 7.70 & 2.38 & 19.02 & 0.00 & 5.73 & 0.18 & 0.00 & 86.70 \\
\hline
\end{tabular}

Note: Microprobe analysis given in weight percent.

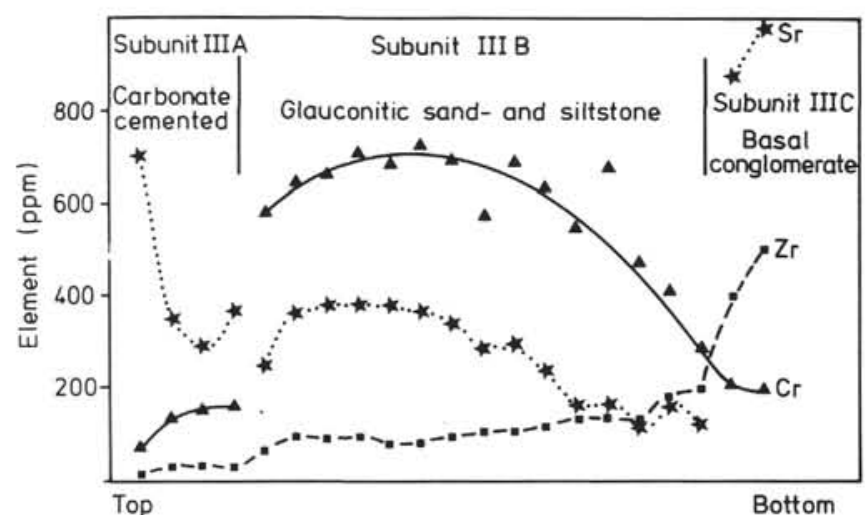

Figure 13. Total-rock $\mathrm{Cr}, \mathrm{Zr}$, and $\mathrm{Sr}$ concentrations of selected samples and stratigraphic affiliation, relative to depth in Hole $748 \mathrm{C}$.

basement of the Southern Kerguelen Plateau. Both options infer shallow upper mantle wedges and possibly major tectonic movements (faulting, uplift, and erosion of the western side of the Banzare Bank). A similar scenario is reported for northwest Spitsbergen, where an alkali-basalt volcanic province with alkali-basalt flows rich in peridotite xenoliths developed at a major tectonic borderline of the northwest Yermak Plateau (Skjeldsvale et al., 1989).

Three igneous sources contributed epiclastic volcanogenic components to the western Raggatt Basin during the Late Cretaceous: (1) an alkali-basalt ocean island (OIB) source with flows rich in peridotite xenoliths or large ultramafic bodies contributing pebbles, Cr-spinel, and $\mathrm{Ti}, \mathrm{Cr}, \mathrm{Zr}$, and $\mathrm{Nb}$ (immobile elements) to the bulk sediment; (2) a T-MORB source contributing plagioclases (probably the highly altered, brown glass shards) and the bulk of the detrital clay; and (3) an (alkali?) rhyolitic source contributing clear quartz, zircon, and alkali feldspar.
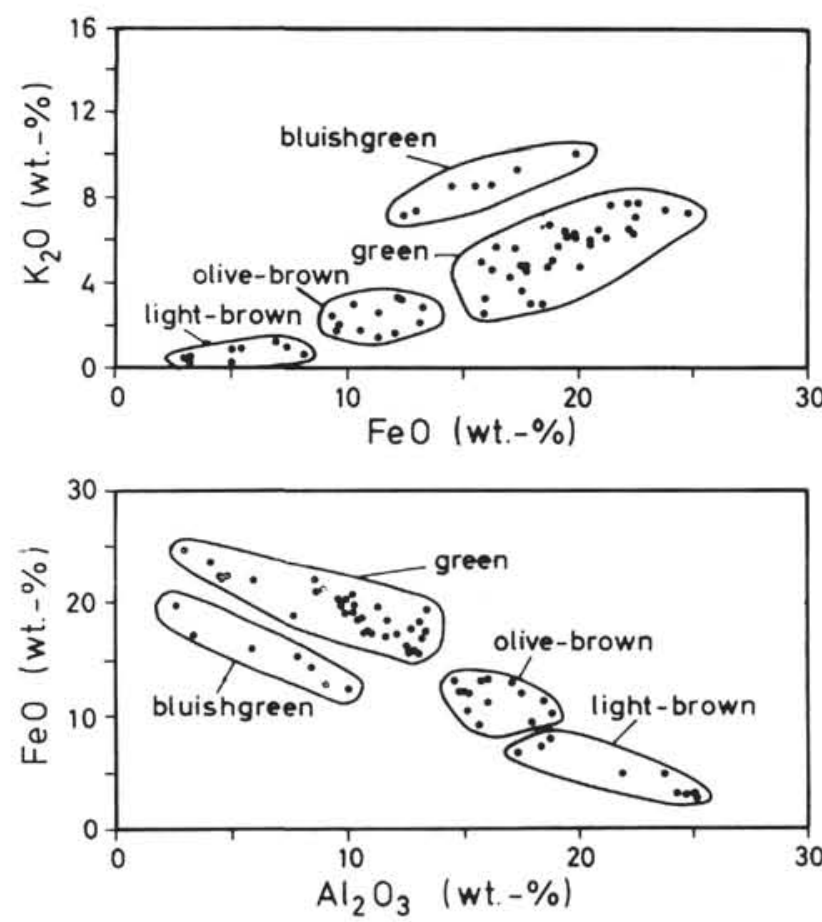

Figure $14 . \mathrm{K}_{2} \mathrm{O}$ vs. $\mathrm{FeO}$ and $\mathrm{FeO}$ vs. $\mathrm{Al}_{2} \mathrm{O}_{3}$ concentrations of discrete varicolored glauconite grains.

\section{Formation of Cr-rich Glauconitic Sediment}

The $\mathrm{Cr}$ incorporated in the brown, glauconitic (clayey) material can be derived from Cr-bearing, natural weathering solutions. In general, natural waters typically do not carry significant amounts of $\mathrm{Cr}$, with a concentration at about $10^{-17}$ 
Table 6. Microprobe analysis of $\mathrm{Cr}$-spinel and ilmenite/magnetite minerals, Hole 748C.

\begin{tabular}{lrrrrrrrr}
\hline $\begin{array}{l}\text { Core, section, } \\
\text { interval (cm) }\end{array}$ & $\mathrm{Al}_{2} \mathrm{O}_{3}$ & $\mathrm{MgO}$ & $\mathrm{FeO}$ & $\mathrm{MnO}$ & $\mathrm{Cr}_{2} \mathrm{O}_{3}$ & $\mathrm{TiO}_{2}$ & Sum & Mineral \\
\hline 120-748C- & & & & & & & & \\
63R-1, 103-105 & 14.85 & 5.51 & 31.25 & 0.08 & 43.81 & 1.73 & 97.23 & $\mathrm{Cr}$ spinel \\
79R-5, 50-52 & 19.77 & 5.57 & 39.69 & 0.47 & 32.49 & 0.41 & 98.40 & $\mathrm{Cr}$ spinel \\
& 16.79 & 5.04 & 43.43 & 0.42 & 31.16 & 0.92 & 97.76 & $\mathrm{Cr}$ spinel \\
& 20.38 & 6.07 & 40.08 & 0.49 & 31.19 & 1.09 & 99.30 & $\mathrm{Cr}$ spinel \\
& 20.32 & 5.72 & 39.11 & 0.58 & 31.98 & 0.39 & 98.10 & $\mathrm{Cr}$ spinel \\
& 19.64 & 5.60 & 40.50 & 0.54 & 30.66 & 0.57 & 97.51 & $\mathrm{Cr}$ spinel \\
79R-4, 107-109 & 19.59 & 7.22 & 30.19 & 0.22 & 38.33 & 1.44 & 96.99 & Cr spinel \\
& 17.67 & 5.92 & 30.39 & 0.10 & 40.53 & 1.97 & 96.58 & Cr spinel \\
& 18.98 & 9.60 & 26.77 & 0.13 & 40.82 & 1.22 & 97.52 & Cr spinel \\
56R-2, 137-144 & 23.67 & 10.83 & 23.20 & 0.02 & 40.63 & 0.94 & 99.29 & Cr spinel \\
& 23.75 & 11.23 & 22.80 & 0.11 & 40.76 & 1.00 & 99.65 & Cr spinel \\
& 0.17 & 1.22 & 47.16 & 0.96 & 0.03 & 48.15 & 97.69 & Ilmenite \\
& 0.15 & 0.23 & 48.59 & 0.23 & 0.00 & 49.54 & 98.74 & Ilmenite \\
79R-4, 35-37 & 0.14 & 1.53 & 47.51 & 0.33 & 0.00 & 50.50 & 99.99 & Ilmenite \\
\hline
\end{tabular}

Note: Microprobe analysis given in weight percent.

Table 7. Microprobe analysis of quartz and feldspar grains, Hole $\mathbf{7 4 8 C}$.

\begin{tabular}{lrrrrrrrrr}
\hline $\begin{array}{l}\text { Core, section, } \\
\text { interval (cm) }\end{array}$ & $\mathrm{Na}_{2} \mathrm{O}$ & $\mathrm{SiO}_{2}$ & $\mathrm{Al}_{2} \mathrm{O}_{3}$ & $\mathrm{MgO}$ & $\mathrm{FeO}$ & $\mathrm{K}_{2} \mathrm{O}$ & $\mathrm{CaO}$ & $\mathrm{Sum}$ & Mineral \\
\hline 120-748C- & & & & & & & & & \\
79R-4, 107-109 & 5.51 & 54.77 & 26.53 & 0.09 & 0.65 & 0.44 & 10.13 & 98.12 & Plagioclase \\
& 4.06 & 52.62 & 28.38 & 0.22 & 0.58 & 0.40 & 12.48 & 98.74 & Plagioclase \\
& 5.94 & 55.85 & 26.96 & 0.02 & 0.75 & 0.43 & 9.69 & 99.64 & Plagioclase \\
& 3.91 & 51.52 & 29.47 & 0.17 & 0.44 & 0.28 & 13.11 & 98.90 & Plagioclase \\
& 4.01 & 51.99 & 29.18 & 0.17 & 0.46 & 0.31 & 12.88 & 99.00 & Plagioclase \\
& 4.03 & 51.92 & 28.97 & 0.15 & 0.53 & 0.33 & 12.85 & 98.78 & Plagioclase \\
& 4.56 & 53.51 & 28.69 & 0.18 & 0.24 & 0.07 & 12.01 & 99.26 & Plagioclase \\
& 4.07 & 51.95 & 29.51 & 0.18 & 0.26 & 0.07 & 12.99 & 99.03 & Plagioclase \\
& 4.38 & 53.73 & 28.81 & 0.23 & 0.47 & 0.14 & 12.38 & 100.14 & Plagioclase \\
& 4.23 & 53.37 & 29.35 & 0.16 & 0.38 & 0.23 & 12.59 & 100.31 & Plagioclase \\
$72 \mathrm{R}-2,53-58$ & 6.04 & 56.85 & 27.01 & 0.07 & 0.70 & 0.27 & 9.13 & 100.07 & Plagioclase \\
& 5.27 & 55.72 & 27.30 & 0.11 & 0.75 & 0.22 & 10.51 & 99.98 & Plagioclase \\
63R-1, 103-105 & 4.55 & 54.10 & 28.28 & 0.17 & 0.74 & 0.29 & 11.83 & 99.96 & Plagioclase \\
& 0.00 & 99.98 & 0.00 & 0.00 & 0.32 & 0.00 & 0.00 & 100.30 & Quartz \\
& 0.00 & 99.45 & 0.12 & 0.00 & 0.30 & 0.00 & 0.00 & 99.87 & Quartz \\
& 0.00 & 99.12 & 0.15 & 0.00 & 0.19 & 0.00 & 0.00 & 99.46 & Quartz \\
& 0.00 & 99.29 & 0.03 & 0.00 & 0.07 & 0.00 & 0.00 & 99.39 & Quartz \\
\hline
\end{tabular}

Note: Microprobe analysis given in weight percent.

Table 8. Microprobe analysis of neoformed carbonate minerals, Hole 748C.

\begin{tabular}{llllllllll}
\hline $\begin{array}{l}\text { Core, section, } \\
\text { interval }(\mathrm{cm})\end{array}$ & $\mathrm{P}_{2} \mathrm{O}_{5}$ & $\mathrm{SiO}_{2}$ & $\mathrm{Al}_{2} \mathrm{O}_{3}$ & $\mathrm{MgO}$ & $\mathrm{FeO}$ & $\mathrm{MnO}$ & $\mathrm{CaO}$ & $\mathrm{Sum}$ & Mineral \\
\hline 120-748C- & & & & & & & & & \\
$79 \mathrm{R}-4,35-37$ & 0.57 & 0.68 & 0.17 & 0.27 & 1.57 & 0.05 & 57.60 & 60.91 & Calcite \\
& 0.66 & 0.06 & 0.01 & 0.48 & 1.64 & 0.24 & 57.92 & 61.01 & Calcite \\
$79 \mathrm{R}-4,35-37$ & 0.11 & 0.09 & 0.04 & 3.97 & 52.24 & 0.76 & 3.23 & 60.44 & Siderite \\
& 0.09 & 0.56 & 0.10 & 4.64 & 54.26 & 0.09 & 1.10 & 60.84 & Siderite \\
$56 \mathrm{R}-2,137-144$ & 0.08 & 1.15 & 0.10 & 6.75 & 46.02 & 0.11 & 4.81 & 59.02 & Siderite \\
\hline
\end{tabular}

moles/L of $\mathrm{CrO}_{4}^{2-}$ (Wedepohl, 1977). Only highly oxidizing conditions allow the formation of $\mathrm{Cr}_{6}^{2-}$, the soluble form of $\mathrm{Cr}$. Oxidizing conditions prevailed during terrestrial weathering, and the erosion of basaltic source rocks may have led to some $\mathrm{Cr}$ dissolution. As soon as $\mathrm{Cr}$-bearing solutions were shed into less oxygenated environments, the $\mathrm{Cr}$ was reduced to its normal quadrivalent state and precipitated in the glauconite pellets and clay material. The suspension of very fine $\mathrm{Cr}$ particles and absorption to clay minerals may be another process for $\mathrm{Cr}$ enrichment of clay minerals.

The glauconite pellets from Hole $748 \mathrm{C}$ differ from the detrital matrix clay by their higher proportions of $\mathrm{K}$ and $\mathrm{Mg}$ and less $\mathrm{Si}$. It is possible that $\mathrm{K}$ and $\mathrm{Mg}$ diffused into fecal pellets and the pores of fossil tests, bypassing the matrix clay, or the glauconite may have crystallized from pore water richer in these elements than the water (presumably soil water) from 
which the detrital clay formed. Alternatively, the glauconite may have "evolved," a process whereby $\mathrm{K}$ is taken up, Si expelled, and interlayering of $10 \downarrow$ layers increases, while the pellet darkens and cracks (Odin and Gullager, 1989).

No depth can be estimated for formation of the lower lithologic subunit, but the presence of red algae in Subunit IIIA indicates shallow-water conditions, only a few tens of meters deep. The sediment overlying Subunit IIIA is a pelagic chalk, indicating that the Southern Kerguelen Plateau sank rapidly during the Late Cretaceous and early Paleogene. It is possible that the sinking was continuous and that the water in which Subunit IIIB was deposited was even shallower than that for Subunit IIIA. Unlike the upper subunit, Subunit IIIB exhibits cross-bedding, indicating currents more vigorous than during the deposition of Subunit IIIA. Both subunits display slight to intense bioturbation, indicating that the sediment was not entirely anoxic. Some factor evidently limited bioproductivity during the deposition of Subunit IIIB. By the time Subunit IIIA was deposited, detrital clay input had gradually ceased and was compensated for by biogenic debris.

\section{Comparison with Other Glauconitic Sediments}

The color and morphology of the Site 748 glauconite pellets strongly resemble glauconite pellets from the Gulf of Guinea, where Odin (1988a) described ochre to dark green colors and small, smooth ellipsoidal to larger, cracked forms. He found an increase in size, cracks, and intensity of the green color correlated with the depth of formation. $\mathrm{K}$ follows that trend, and there is a negative correlation in the $\mathrm{Fe}$ and $\mathrm{Al}$ concentrations of the distinctly colored glauconite grains, a trend we also observed in the Site 748 glauconites (Fig. 14). The environmental setting in the Gulf of Guinea is a continental shelf platform (with a surface of about $3200 \mathrm{~km}^{2}$ and $120 \mathrm{~m}$ deep) where the ochre glauconite forms and a slope region where the deep green, high-K glauconite forms. The terrestrial, tropically forested backland is a peneplain drained by two rivers, which carry fresh water with as much as $255 \mathrm{mg} / \mathrm{L}$ $\mathrm{Fe}$ into the gulf. The glauconite develops at the sediment/ seawater boundary, but are reworked through bottom currents, and thus mixed green and ochre, round and cracked glauconite pellets occur in the sediment. The conditions for glauconite formation and accumulation in the Gulf of Guinea, as described by Odin (1988a), seem similar to what we observed in the glauconitic sequence at Site 748 .

\section{Paleoenvironmental Aspects}

The basal conglomerate at Site 748 records the erosion and reworking of the underlying alkali-basalt flow. The soft pebbles, a few chips from the poorly recovered section below the alkali-basalt flow, and the epiclastic sediment at Site 750 reveal the terrestrial and climatic history before and during formation of the glauconitic sediment. The Southern Kerguelen Plateau volcanic edifices (T-MORB plateau basalts, alkali basalts with ultramafics) were in emergent to shallowmarine conditions and subject to intense weathering under temperate to subtropical conditions. Well-vegetated forests developed in a subaqueous to subaerial environment similar to a marshy flood plain (Schlich, Wise, et al., 1989).

A change from the restricted inner shelf to biologically more active conditions occurred some time during the Campanian/Turonian. This change (top of Subunit IIIB, which is also a seismic reflector) is indicated by an increasing bioclastic and decreasing clay input.

In the latest Maestrichtian or early Paleocene, a profound deepening of this site occurred and glauconite formation and terrestrial input virtually ceased; Site 748 has remained in the pelagic realm ever since.

\section{Volcanotectonic Evolution of the Western Raggatt Basin in the Late Cretaceous}

Basement of the Southern Kerguelen Plateau consists of oceanic plateau basalts of T-MORB composition. These basalts were extruded quietly under subaerial to shallow-marine conditions (Bassias et al., 1987; Schlich, Wise, et al., 1989; Mehl et al., 1990) and belong to the plateau-forming stage of the formation of the Kerguelen Plateau (Bitschene et al., 1989). In a transitional and early rifting stage (pre-Cenomanian), the basaltic basement was weathered under temperate to subtropical conditions (Holmes, this volume), and the Site 748 alkali basalts were erupted. The landscape may have developed huge volcanic edifices (OIB-type) bordering an incipient Raggatt Basin (Rotstein et al., in press). The glauconitic sediment at Site 748 reflects the weathering, erosion, and submergence of an oceanic island or islands sitting upon an oceanic plateau. The basal conglomerate denotes erosion of OIB-type alkali-basalt flows. Subunit IIIB records the input of basaltic, ultrabasic, and rhyolitic epiclastic particles from a terrestrial hinterland; Subunit IIIA reveals the waning influence of the foundering hinterland and high biogenic productivity. The entire sequence is the first truly marine sediment recovered to date in this part of the Southern Kerguelen Plateau and reflects sediment accumulation in the initially slowly subsiding Raggatt Basin. Slow subsidence of this inner-shelf region with shallow-water and low-energy conditions favored glauconite formation. Following an unconformity (top of Subunit IIIA; Schlich, Wise, et al., 1989) the Raggatt Basin underwent rapid submergence.

Slow subsidence and synsedimentary faulting, a process that commonly accounts for regionally and locally varying sediment thicknesses and facies during rift-related graben formation, lasted until about the early Maestrichtian. Sedimentation kept pace with subsidence so that shallow water depths prevailed in the Raggatt Basin during mid-Campanian through late Maestrichtian times. The glauconitic sedimentation ended in the latest Maestrichtian, when a major geotectonic event caused a sharp break toward deep marine lithologic types.

\section{Regional Tectonic Implications}

The findings from the Site 748 glauconitic sequence are a record of the early evolution (as old as Early Cretaceous) of the Raggatt Basin on the Southern Kerguelen Plateau. Alteration and erosion of the volcanic edifices in the hinterland and slow subsidence accompanied by synsedimentary faulting link the evolution of the Raggatt Basin with early extensional and rifting tectonics in the Southern Kerguelen Plateau, which was probably a precursor to major rifting between the Kerguelen Plateau and the Broken Ridge/Diamantina Fracture Zones. These somewhat tentative conclusions are in basic accordance with the results from previous investigations. Quilty (1973) concluded from piston cores taken northeast of the Southern Kerguelen Plateau that the initial breakup between Broken Ridge and Kerguelen Plateau started at least in Cenomanian times. From seismic, gravimetric, and geographic observations, Mutter and Cande (1983) and Mutter et al. (1985) concluded that the breakup chronology of Australia and Antarctica began at least $90 \mathrm{~m}$.y. ago, initially at a slow rate.

Ramsay et al. (1986) first described the Raggatt Basin with $>4 \mathrm{~km}$ of sediment thickness, bounded by normal faults and basement blocks. An Early Cretaceous age for the Raggatt Basin formation is favored, which is in agreement with the data from Sites 748 and 750 only if we attribute this age to the silty and clayey terrestrial to fluviatile-littoral sediments be- 
low the alkali basalt at Site 748 and above the basement at Site 750. Ramsay et al. (1986) noted several unconformities in the sediment fill but denied significant faulting. The resolution of their techniques, however, limits the detection of small-scale (tens of meters) synsedimentary faults. Coffin et al. (1986) interpreted the Southern Kerguelen Plateau as a single broad anticlinal arch disturbed by various faults that have been active over a long time. Coffin et al. (1990) interpreted anew the seismic stratigraphy of the Raggatt Basin and concluded that tectonism and paleoceanographic conditions were the major factors affecting sedimentation in the Raggatt Basin, perhaps in coincidence with extensional faulting on the western flank of the Southern Kerguelen Plateau. The idea of a link between the Raggatt Basin and the evolution of volcanic edifices was stressed by Rotstein et al. (in press). They considered the Raggatt Basin as the low area between former volcanoes, particularly on the Banzare Bank to the west.

In summary, the interpretation of approximately the same seismic data set ranges from nontectonic basement subsidence to fully tectonic-induced evolution of the Raggatt Basin. Our interpretation favors the concept of gentle subsidence and steady synsedimentary small-scale tectonic movements punctuated by major tectonic episodes. This picture is reflected by the glauconitic sediments from Site 748 , which are the ultimate sink for the eroded volcanic edifices. Our investigation detected, in addition to the expected T-MORB and OIB, the likely presence of ultrabasic bodies and evolved, rhyolitic massifs somewhere in the hinterland. Some of these volcanic edifices emerged as oceanic islands above sea level, in a volcanotectonic situation similar to what we observe today on the Northern Kerguelen Plateau with the Kerguelen Island and Heard Island volcanoes. The similarities between the Late Cretaceous oceanic island scenario on the Southern Kerguelen Plateau and the Neogene to Holocene oceanic island scenario are even more convincing when we include the results from cores taken at the northeastern border of the Northern Kerguelen Plateau, where glauconite developed from pumice debris that originated from Kerguelen and Heard islands (Odin and Fröhlich, 1988).

\section{Global Significance of Glauconite Sediments from Basaltic Oceanic Plateaus}

The widespread occurrence of glauconite pellets in the Cretaceous Indian Ocean and the sustained formation at Site 748 suggest that oceanographic conditions especially conducive to glauconite formation prevailed throughout this area at that time. In addition, analogies exist in the evolution of glauconitic sequences on other oceanic plateaus. Paleogene glauconitic sequences on the Vøring Plateau were drilled during DSDP Leg 38 and ODP Leg 104 (Talwani, Udintsev, et al., 1976; Eldholm, Thiede, Taylor, et al., 1987), whereas Upper Cretaceous glauconitic sediments were recovered from the Southern Kerguelen Plateau during Leg 120. These glauconitic sequences (1) rest upon basaltic basement and its alteration products, (2) are sinks for volcanogenic particles and solutions, (3) represent the first true marine sediments on these plateaus after the cessation of plateau volcanism, and (4) can be interpreted as epiclastic sediments drained from the volcanic terrestrial hinterland. The geotectonic significance of these sediments is that they record the dynamic transition in time and lithology from (1) subaerial to submarine, (2) volcanic to nonvolcanic, and (3) slow submergence to rapid foundering. Therefore, they can be interpreted as typical transgressive sequences reflecting the transition of pericontinental basaltic plateaus from tranquil platform to active rifting stages (Bitschene et al., 1989). This hypothesis has to be tested further, but it extends Odin and Fullagar's (1988) findings for the geologic significance of glauconite. They compiled the data available on the physical, chemical, environmental, and genetic aspects of glauconite formation. They also considered $\mathrm{K}$-rich glauconites $\left(>7 \% \mathrm{~K}_{2} \mathrm{O}\right)$ indicative of geologically significant breaks in sedimentation, because glauconite forms at the sediment/seawater interface. This geologic break is estimated to last about $10^{4}-10^{5} \mathrm{yr}$, and even more time $\left(10^{6} \mathrm{yr}\right)$ is required for deep green, high-K glauconites. From these considerations, it is possible that the Site 748 glauconitic sequence did not form completely in situ, but resulted from reworking of vast areas with low sedimentation rates favorable for glauconite formation and from shedding and accumulation of the sediment pile into the more rapidly foundering parts of the Raggatt Basin. Sea-level changes, however, and transgressive sequences are commonly marked by highly glauconitic basal layers (Odin and Fullagar, 1988).

\section{CONCLUSIONS}

Subunits IIIC and IIIB of the glauconitic sequence formed by deposition of glauconite pellets, volcanogenic components, and clayey sediments, which were transported restricted distances and redeposited by successive mass-transport processes. Subunit IIIA of the glauconitic sequence developed in a nearshore, shallow-marine environment with high biogenic productivity.

Epiclastic light minerals, basaltic clasts, and $\mathrm{Cr}$ and $\mathrm{Ti}$ ore mineral assemblages were contributed from volcanic sources. The volcanic edifices exposed consisted of tholeiitic (ridge?) basalts, alkali basalts with ultramafic bodies, and rhyolitic centers. They probably rested upon today's Banzare Bank to the west, but oceanic islands may have existed elsewhere.

Aqueous solutions carried $\mathrm{Fe}, \mathrm{K}, \mathrm{Cr}, \mathrm{Si}$, and possibly $\mathrm{Al}$, derived from basaltic (tholeiitic, alkali basaltic, and ultrabasic) and most probably minor rhyolitic sources, weathered under tropical to subtropical, highly oxidizing conditions. In particular, Subunits IIIC and IIIB reveal the exposure of alkalibasalt, OIB-type volcanic edifices with large ultramafic bodies or appreciable amounts of peridotic xenoliths.

The glauconitic sequence comprises the transition in space and time from terrestrial to marine, from magmatically active subaerial to magmatically passive submarine, and from tranquil platform to active rifting conditions.

Together with similar conditions and evolutionary trends on the Vøring Plateau (North Atlantic), the glauconitic sequences with an epiclastic volcanogenic input mark the transition from a passive continental plateau to active rifting and, finally, open-ocean conditions.

\section{ACKNOWLEDGMENTS}

This project was funded by the Deutsche Forschungsgemeinschaft through grants Schm 37/1-3 (Seamount Evolution) to Hans Ulrich Schmincke and by the National Science Foundation through the Joint Oceanographic Institutions/ United States Science Advisory Committee to Mary Anne Holmes and James Breza. At Bochum, B. Schulz and H. Niephaus helped with the XRF work, H.-J. Bernhardt provided technical assistance during the microprobe work, and J. Dehn and K. Mehl assisted with the computational work. At Nebraska, Kit Lee and Ming Q. Yang assisted with SEM/EDX analysis; Waldemir Faryna with the Rigaku XRD; Terri Dunn and Huaibao Liu with sample preparation; and Xiuying Liu with sample preparation, including glauconite picking, and the Soil Conservation Service of the United States Department of Agriculture through Steve Halzhey and S. Legeros graciously allowed generous amounts of time on the Philips XRD. Critical readings by W. van Houtenand and an anonymous reviewer are gratefully acknowledged. Above all, we extend our sincerest 
thanks to the Leg 120 shipboard scientific, technical, and drilling crews, who managed the drilling, recovery, and first shipboard evaluation of this unique sequence. This contribution is dedicated to the memory of Lamar Hayes.

\section{REFERENCES}

Bailey, S. W., 1980. Structures of layer silicates. In Brindley, G. W., and Brown, G. (Eds.), Crystal Structures of Clay Minerals and Their $X$-ray Identification. Mineral. Soc. London Monogr., 5:1-124.

Barron, J., Larsen, B., et al., 1989. Proc. ODP, Init. Repts., 119: College Station, TX (Ocean Drilling Program).

Bassias, Y., Davies, H. L., Leclaire, L., and Weis, D., 1987. Basaltic basement and sedimentary rocks from the southern sector of the Kerguelen-Heard Plateau: new data and their Meso-Cenozoic paleogeographic and geodynamic implication. Bull. Mus. Natl. Hist. Nat., Sect. C, 9:367-403.

Bell, D. L., and Goodell, H. G., 1967. A comparative study of glauconite and the associated clay fraction in modern marine sediments. Sedimentology, 9:169-202.

Bentor, Y. K., and Kastner, M., 1965. Notes on the mineralogy and origin of glauconite. J. Sediment. Petrol., 35:155-166.

Bitschene, P. R., Holmes, M.-A., Breza, J., and Leg 120 Shipboard Party, 1989. Composition and geotectonic significance of Cr-rich glauconitic sediments from Site 748 (Leg 120, Kerguelen Plateau, southern Indian Ocean). 28th Int. Geol. Congr., Wash./DC, I:156157. (Abstract).

Bornhold, B. D., and Giresse, P., 1985. Glauconitic sediments on the continental shelf off Vancouver Island (Canada). J. Sediment. Petrol., 55:653-664.

Burst, J. F., 1958. "Glauconite" pellets: their mineral nature and applications to stratigraphic interpretations. AAPG Bull., 42:310337.

Chapman, H. D., 1965. Cation-exchange capacity. In Black, C. A., Evans, D. D., White, J. L., Ensminger, L. E., Clark, F. E., and Dinauer, R. C. (Eds.), Methods of Soil Analysis Part 2-Chemical and Microbiological Properties: Madison, WI (Am. Soc. Agron., Inc.), 891-901.

Coffin, M. F., Davies, H. L., and Haxby, W. F., 1986. Structure of the Kerguelen Plateau province from SEASAT altimetry and seismic reflection data. Nature, 324:134-136.

Coffin, M. F., Munschy, M., Colwell, J. B., Schlich, R., Davies, H. L., and Li, Z.-G., 1990. Seismic stratigraphy of the Raggatt Basin, southern Kerguelen Plateau: tectonic and paleoceanographic implications. Geol. Soc. Am. Bull., 102:563-579.

Davies, T. A., Luyendyk, B. P., et al., 1974. Init. Repts., DSDP, 26: Washington (U.S. Govt. Printing Office).

Eldholm, O., Thiede, J., Taylor, E., et al., 1987. Proc. ODP, Init. Repts., 104: College Station, TX (Ocean Drilling Program).

Eslinger, E., and Pevear, D., 1988. Clay minerals for petroleum geologists and engineers. SEPM Short Course Notes, 22.

Fischer, H., 1987. Excess K-Ar ages of glauconite from the Upper Marine Molasse and evidence for glauconitization of mica. Geol. Rundsch., 76:885-902.

Friedman, G. M., 1962. On sorting, sorting coefficients and the log normality of the grain-size distribution of sandstones. J. Geol., 70:737-753.

Galliher, E. W., 1939. Biotite-glauconite transformation and associated minerals. In Trask, P. D. (Ed.), Recent Marine Sediments. AAPG, 513-515.

Hamlyn, P. R., and Bonatti, E., 1980. Petrology of mantle derived ultramafics from the Owen fracture zone, northwest Indian Ocean: implications for the nature of the oceanic upper mantle. Earth Planet. Sci. Lett., 48:65-79.

Hower, J., 1961. Some factors concerning the nature and origin of glauconite. Am. Mineral., 46:313-334.

Hughes, A. D., and Whitehead, D., 1987. Glauconitization of detrital silica substrates in the Barton Formation (upper Eocene) of the Hampshire Basin, southern England. Sedimentology, 34:835-835.

Jones, J. B., and Segnit, E. R., 1971. The nature of opal I. Nomenclature and constituent phases. J. Geol. Soc. Aust., 18:57-68.

Kirkpatrick, G. L., 1982. Statistical analysis of grain size data as a possible key to ancient depositional environments [M.S. thesis]. Florida State Univ., Tallahassee, FL.
Lewis, D. W., 1984. Practical Sedimentology: New York (Van Nostrand Reinhold).

McRae, S. G., 1972. Glauconite. Earth-Sci. Rev., 8:397-440.

Mehl, K., Bitschene, P. R., Schmincke, H.-U., and Hertogen, J., 1990. Composition, alteration, and origin of the basement lavas and volcaniclastic rocks at Site 738, southern Kerguelen Plateau. In Barron, T., Larsen, B., et al., Proc. ODP, Sci. Results, 119: College Station, TX (Ocean Drilling Program), 299-322.

Mumpton, F. A., 1960. Clinoptilolite redefined. Am. Mineral., 45:351-369.

Mutter, J. C., and Cande, S. C., 1983. The early opening between Broken Ridge and Kerguelen Plateau. Earth Planet. Sci. Lett., 65:369-376.

Mutter, J. C., Hegarty, K. A., Cande, S. C., and Weissel, J. K., 1985. Breakup between Australia and Antarctica: a brief review in the light of new data. Tectonophysics, 114:255-279.

Newman, A.C.D., and Brown, G., 1987. The chemical constitution of clays. In Newman, A.C.D. (Ed.), Chemistry of Clays and Clay Minerals: Mineral. Soc. Monogr., 6:1-128.

Odin, G. S., 1972. Observations nouvelle sur la structure de la glauconie en accordéon; descrocion du processus de genèse par néoformation. Sedimentology, 19:285-294. 1988a. Glaucony from the Gulf of Guinea. In Odin, G. S. (Ed.), Green Marine Clays: Amsterdam (Elsevier), 225-246. (Ed.), 1988b. Green Marine Clays: Amsterdam (Elsevier).

Odin, G. S., and Fröhlich, F., 1988. Glaucony from the Kerguelen Plateau. In Odin, G. S. (Ed.), Green Marine Clays: Amsterdam (Elsevier), 277-294.

Odin, G. S., and Fullagar, P. D., 1988. Geological significance of the glaucony facies. In Odin, G. S. (Ed.), Green Marine Clays: Amsterdam (Elsevier), 45:295-332.

Odin, G. S., and Lamboy, M., 1988. Glaucony from the margin off northwestern Spain. In Odin, G. S. (Ed.), Green Marine Clays: Amsterdam (Elsevier), 249-276.

Odin, G. S., and Matter, A., 1981. De glauconiarum origine. Sedimentology, 28:611-641.

Pettijohn, E. J., Potter, P. E., and Siever, R., 1973. Sand and Sandstone: New York (Springer-Verlag).

Playford, P. E., Cope, R. N., Cockbain, A. E., Low, G. H., and Lowry, G. C., 1975. Phanerozoic geology of western Australia. West. Aust. Geol. Surv. Mem., 2:221-433.

Pollastro, R. M., 1982. A recommended procedure for the preparation of oriented clay-mineral specimens for X-ray diffraction analysis: modification to Drever's filter-membrane peel technique. OpenFile Rep.-U.S. Geol. Surv., 71-82.

Quilty, P. G., 1973. Cenomanian-Turonian and Neogene sediments from northeast of Kerguelen Ridge, Indian Ocean. J. Geol. Soc. Aust., 20:361-371.

Ramdohr, P., 1975. Die Erzmineralien und ihre Verwachsungen. 4. Bearbeitete und Erweiterte Auflage: Berlin (Akademie Verlag).

Ramsay, D. C., Colwell, J. B., Coffin, M. F., Davies, H. L., Hill, P. J., Pigram, C. J., and Stagg, H.M.J., 1986. New findings from the Kerguelen Plateau. Geology, 14:589-593.

Reynolds, R. C., 1980. Interstratified clay minerals. In Brindley, G. W., and Brown, G. (Eds.), Crystal Structures of Clay Minerals and their X-Ray Identification. Mineral. Soc. London Monogr., $5: 249-303$.

Royer, J.-Y., and Sandwell, D. G., 1989. Evolution of the eastern Indian Ocean since the Late Cretaceous: constraints from Geosat altimetry. J. Geophys. Res., 94:755-782.

Rotstein, Y., Schaming, M., Schlich, R., and Colwell, J. B., in press. Basin evolution in oceanic plateaus: seismic reflection evidence from the Kerguelen Plateau, South Indian Ocean. Mar. Petrol. Geol.

Schlich, R., Wise, S. W., Jr., et al., 1989. Proc, ODP, Init. Repts., 120: College Station, TX (Ocean Drilling Program).

Skjeldsvale, B. L., Amundsen, H.E.F., O'Reilly, P., Griffin, W. L., and Gjelsvik, R., 1989. A primitive alkalibasaltic stratovolcano and associated eruptive centers, northwestern Spitsbergen: volcanology and geotectonic significance. J. Volcanol. Geotherm. Res., 37:1-19.

Talwani, M., Udintsev, G., et al., 1976. Init. Repts. DSDP, 38: Washington (U.S. Govt. Printing Office). 
Thompson, G. R., and Hower, J., 1975. The mineralogy of glauconite. Clays Clay Miner., 23:289-300.

Triplehorn, D. M., 1966. Morphology, internal structure and origin of glauconite pellets. Sedimentology, 6:247-266.

von der Borch, C. C., Sclater, J. G., et al., 1974. Init. Repts. DSDP. 22: Washington (U.S. Govt. Printing Office).
Wedepohl, K., 1977. Chromium. In Wedepohl, K. (Ed.), Handbook of Geochemistry: Berlin (Springer-Verlag).

Date of initial receipt: 26 February 1990

Date of acceptance: 11 January 1991

Ms 120B-133 

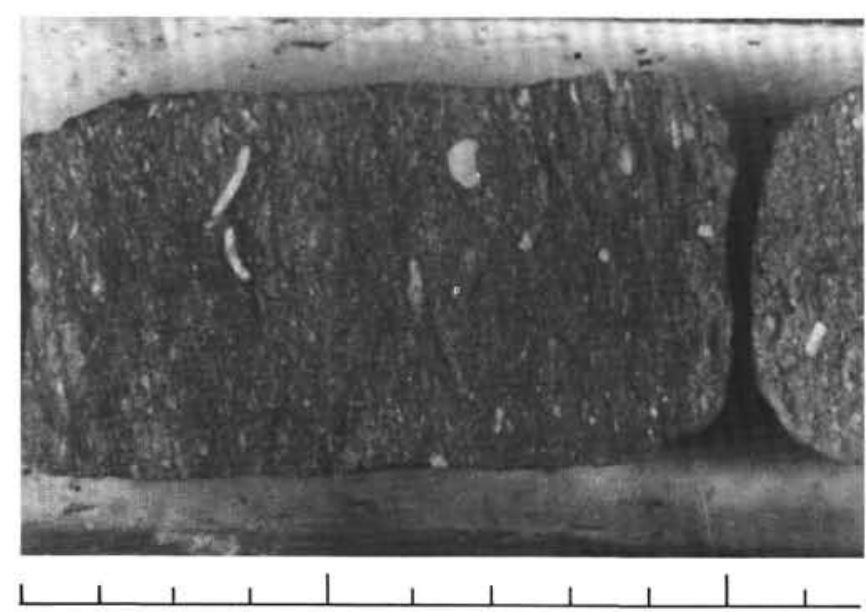

5

10

1

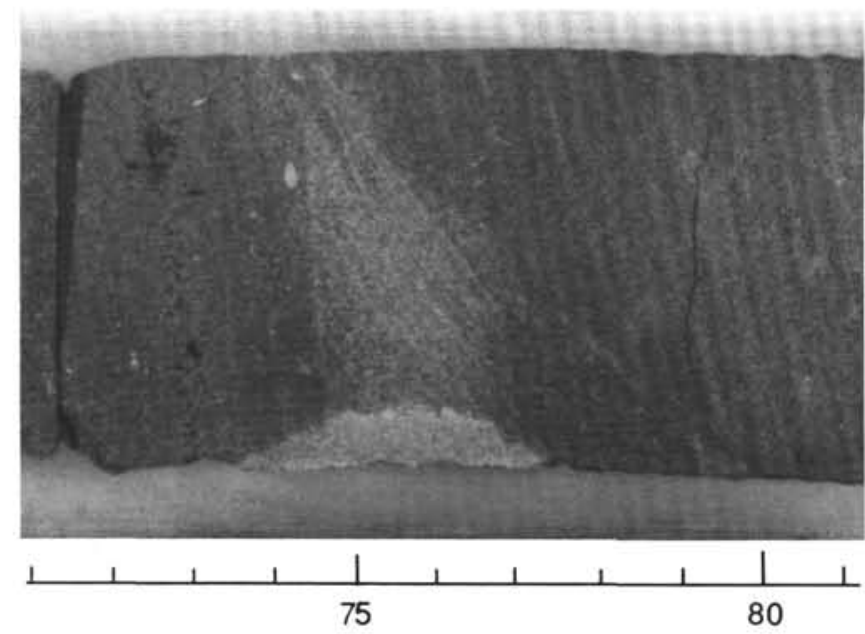

3

Plate 1. Core photographs. 1. Glauconitic packstone from Subunit IIIA, Section 120-748C-45R-CC. Inoceramid debris at 3 and $11 \mathrm{~cm}$; bryozoan debris between 7 and $10 \mathrm{~cm}$. Dark brown, thin, clay-rich flaser beds are especially abundant between 7 and $10 \mathrm{~cm}$. 2 . Light to dark clay-filled burrows in glauconitic packstone from Subunit IIIA, Section 120-748C-46R-1. The mollusk between 50 and $52 \mathrm{~cm}$ is filled with glauconite, micrite, and pyrite. 3. Glauconitic siltstone from Subunit IIIB, Section 120-748C-72R-4. Cross-beds between 74 and $84 \mathrm{~cm}$ indicate deposition by currents. Pyritized wood is concentrated along bedding planes at $73 \mathrm{~cm}$. A siderite concretion has formed across cross-beds and planar beds from 73 to $77 \mathrm{~cm}$. 4. Upper part of conglomerate from Subunit IIIC, Section 120-748C-79R-4. Dark gray, rounded basalt cobbles are mixed with unaltered, mollusk fragments in glauconitic siltstone. Postdepositional bioturbation is evident from the large burrows. 



$800 \mu \mathrm{m}$

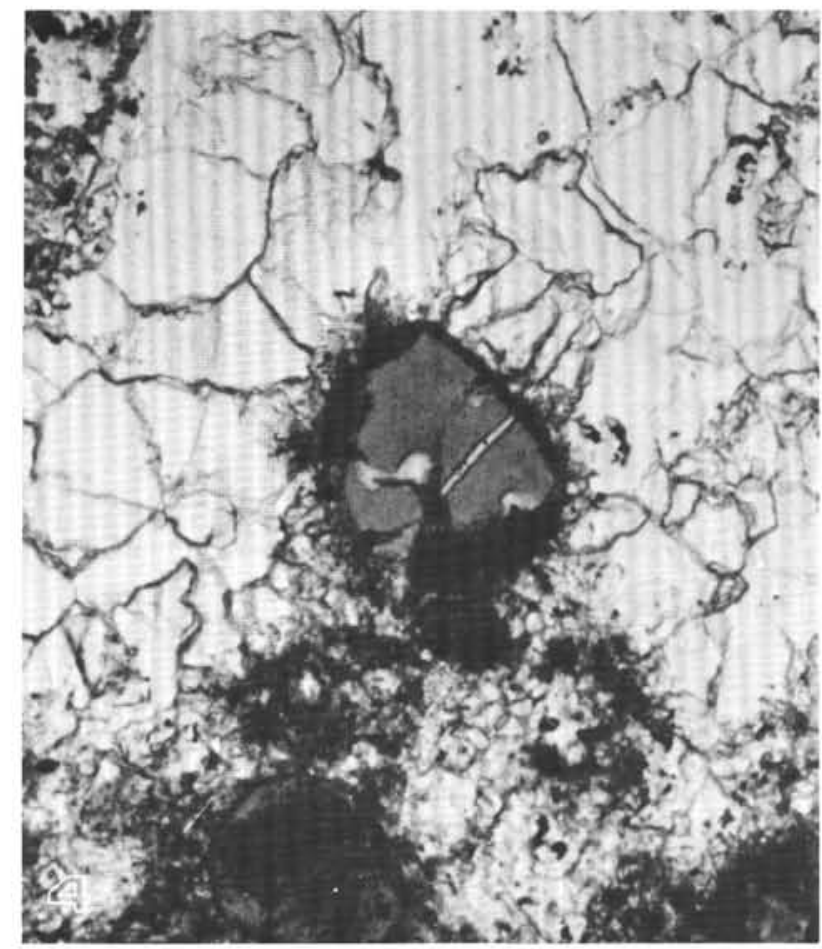

$200 \mu \mathrm{m}$

Plate 2. Thin section photographs. 1. Brown, translucent $\mathrm{Cr}$-spinel grain with carbonate fossil debris set into a matrix of brown glauconite and clayey minerals. 2. Blocky and cracked and minor oval, smooth glauconite grains with color zonation (dark green core with pyrite, light olive-brown rim without pyrite) and some plagioclase laths and opaque Fe-Ti ore splinters in a carbonate matrix. $\mathbf{3}$. Rounded alkali-basalt pebble with glauconitic and clayey matrix. 4. Relict platy glass shard in carbonate matrix. 